\title{
DIGITALCOMMONS
}

@WAYNESTATE -

Wayne State University

$1-1-2016$

\section{The Enduring Ambiguities of Antitrust Liability for Worker Collective Action}

Sanjukta M. Paul

Wayne State University

Follow this and additional works at: https://digitalcommons.wayne.edu/lawfrp

Part of the Business Organizations Law Commons

\section{Recommended Citation}

Sanjukta M. Paul, The Enduring Ambiguities of Antitrust Liability for Worker Collective Action, 47 Loy. U. Chi. L.J. 969, 1048 (2016)

This Article is brought to you for free and open access by the Law School at DigitalCommons@WayneState. It has been accepted for inclusion in Law Faculty Research Publications by an authorized administrator of DigitalCommons@WayneState. 


\title{
The Enduring Ambiguities of Antitrust Liability for Worker Collective Action
}

\author{
Sanjukta M. Paul*
}

This Article examines the regulation, by antitrust law, of collective action by low-wage workers who are classified as independent contractors, and who therefore presumptively do not receive the benefit of the labor exemption from antitrust law. Such workers find themselves in the position of most workers prior to the New Deal: at once lacking labor protections, yet exposed to antitrust liability for organizing to improve their conditions. I argue that this default rule is the legacy of a problematic history that is taken for granted by the contemporary antitrust framework.

In Part I, I show that the threat of antitrust liability is a powerful constraint upon contemporary independent contractor workers' own ability to take action to address their working conditions. In Part II, I trace the application of antitrust liability to worker collective action to the time before the labor exemption, arguing that pre-New Deal courts imported fundamentally hierarchical and coercive tenets from the common-law tradition into the fledgling antitrust law in order to apply it to contain worker organizing, thereby creating tensions with their own freedom of contract principles. In Part III, I show how the legal framework of the labor exemption reinforced the underlying assumption that antitrust regulates worker collective action, even as it immunized most workers from such liability (so long as they continued to be

\footnotetext{
* David J. Epstein Fellow, UCLA School of Law. The guidance, interlocution, and inspiration I have received from Noah Zatz have been essential to this project. Julia Tomassetti's comments on an earlier draft were also especially pivotal. I am grateful too to Scott Cummings, William Forbath, John Howe, Ethan Leib, Shae McCrystal, and Suresh Naidu for their insightful thoughts and comments at various points. This Article has also benefitted from audience comments at the Labour Law Research Network conference (University of Amsterdam), the Law \& Society conference, the Class Crits conference (UC-Davis), and the Eighth Annual Colloquium on Scholarship in Labọ \& Employment Law (UNLV). I thank Garth Bostic for his able research assistance, Linda Karr O'Connor and Elyse Meyers of the UCLA Law Library for their valuable contributions, and UCLA School of Law for supporting this project. Finally, I thank Benjamin Barnett, as well as the other editors of the Loyola University Chicago Law Journal, whose thoughtful care and attention to this Article has improved it greatly.
} 
considered employees). In Part IV, I argue that the modern framework for antitrust does not compel the continued application of this default rule, and indeed supplies materials for a fresh, more balanced reconsideration of it.

Ultimately, the situation of these workers is a test of what antitrust fundamentally says about labor, absent a specific exemption. Because that exemption is currently rooted in the New Deal network of labor regulation, antitrust's treatment of labor becomes a baseline for critical conversations about how to reform our curient framework of labor regulation-in the same way that it was the baseline for those conversations prior to the New Deal itself. In particular, antitrust functions as an outer limit for any such reform, and also for specific policy proposals to address the increasing prevalence of working relationships outside the bounds of employment.

INTRODUCTION

I. THE IMPACT OF ANTITRUST ON CONTEMPORARY INDEPENDENT CONTRACTOR WORKERS 976

A. The Struggle for Decent Work and Decent Pay as Price-Fixing 977

B. An Object Lesson in the Revival of Antitrust as a Bar to Worker Collective Action 979

C. Universe of Potential Defendants 984

D. Intersection with Work Law 986

II. Of MARKETS, COMBINATIONS, AND SERVANTS: How ANTITRUST LAW CAME TO PUNiSH WORKER COLleCtive ACTION. 990

A. Classicist Trade Regulation and Nineteenth-Century Labor Regulation

1. Classicist Trade Regulation 993

2. Labor Regulation in the Gilded Age 995

B. The Sherman Act and Its Relationship to Labor 997

C. Parity: A Bridge from Feudal Labor Regulation to Modern Trade Regulation. 1000

1. The Argument from Parity. 1001

2. Implementing Parity in the Courts 1004

a. The Workingmen's Amalgamated Case: Three Ambiguous "Evils" 1004

i. Violence and Coercion Toward Unwilling Third Parties.

ii. Interrupting Commerce by Refusing to Work ... 1008 
iii. A Work Stoppage Aimed at Improvement of Working Conditions........................................... 1010

b. The Danbury Hatters Case ....................................... 1013

3. The Corporate Exemption ............................................... 1016

III. THE LABOR EXEMPTION: AN UNSTABLE PARADIGM .................... 1020

A. The Norris-La Guardia Act ................................................ 1021

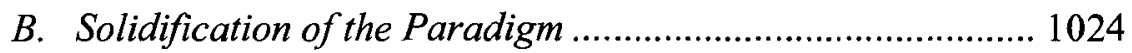

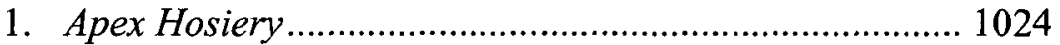

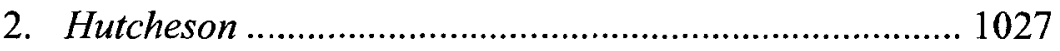

C. The Normal Science of the Labor Exemption........................ 1028

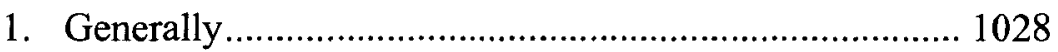

2. Normal Science Case Law and "Independent 1030

IV. ANTITRUST LIABILITY FOR WORKER COLLECTIVE ACTION:

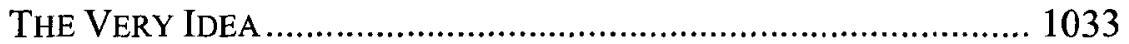

A. The Inherent Normative Content of Punishing Worker

Collective Action Under Antitrust ....................................... 1034

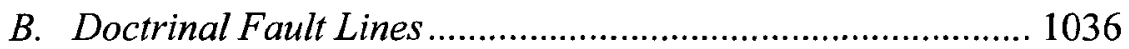

1. The Wayward Meaning of Price-Fixing ......................... 1036

2. The Professional Privilege ............................................ 1041

3. First Amendment Protection for Worker Collective Action?: "Economic" and "Political" Protest ................. 1043

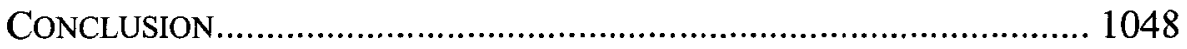

\section{INTRODUCTION}

In the winter of 1999 , following a series of strikes at America's ports aimed at improving poor working conditions and low pay, a number of individual truck drivers found themselves served with subpoenas by the U.S. Federal Trade Commission ("FTC"), which was investigating their potential participation in a price-fixing conspiracy. ${ }^{1}$ These men, who were working punishing hours yet hardly breaking even, were grassroots leaders in an episode of collective action among low-wage workers that was somewhat unusual for the period. Their participation and leadership in these expressions of solidarity was the basis for the investigation.

1. See infra Part I.B (discussing antitrust as a barrier to worker collective action). 
In this Article, I examine the origins of the rule that antitrust law largely prohibits collective action by workers who fall outside the bounds of employment, and who therefore presumptively do not receive the benefit of the labor exemption from antitrust law. ${ }^{2}$ The threat that organizing for decent wages and working conditions will be prosecuted as price-fixing is a powerful constraint upon such workers' ability to take action to change their circumstances. Antitrust has historically structured the nature and content of labor regulation in this country, and it is currently poised to do so again in a new form. It did so directly and punitively in the Gilded Age. It did so indirectly and somewhat under the surface during the New Deal era. In today's deregulation era, it is of increasing significance in regulating workers who fall outside the bounds of the National Labor Relations Act ("NLRA") ${ }^{3}$ (and other employment and labor law), as a limit upon new forms of labor regulation that would bring these nontraditional workers within their scope, and as a potential baseline for labor law reform generally. In contrast to the neoclassical interpretation of antitrust, which holds that the doctrine is justified on economic grounds independent of politics and moral norms, I adopt the perspective that antitrust has essential and irreducible political or normative content. While the neoclassical interpretation has certainly been challenged, it still holds great sway as the official position of most courts and the mainstream of antitrust scholarship. Antitrust's normative content can specifically be seen in its relationship to labor, which has changed over time according to the specific policy project and broader norms that held purchase among decision makers.

Antitrust law had its origins in a republican outlook that viewed emerging concentrations of economic and political power, enabled by the rise of the modern business corporation, as highly problematic. The statute was not, originally, intended to apply to workers' or farmers' collective action. The policy project envisioned by the legislators - breaking up concentrations of economic powerwould in fact be undermined by preventing cooperation among lesspowerful economic actors who were affected by large business combinations. ${ }^{4}$

2. See infra Part III.C.2.

3. National Labor Relations Act of 1935 , ch. 372,49 Stat. 449 (codified as amended at 29 U.S.C. $\S \S 151-169(2012))$.

4. See infra Part II.B (discussing the Sherman Act and its relationship to labor). 
This original orientation took a sharp turn in the courts, where a different and somewhat competing policy project, that of building the national market society, held greater sway. That project benefited from a compliant and reliable workforce. In order to use antitrust to prevent and punish worker organizing, Gilded Age courts made use of an equivocation in the concept of "free trade," and drew on fundamentally hierarchical and coercive assumptions regarding workers from the common law of labor regulation. ${ }^{5}$ In purporting to implement parity between capital and labor under antitrust regulation, the courts actually relied upon status-based normative assumptions regarding workers qua workers. ${ }^{6}$

These courts succeeded in making the presumptive illicitness of worker collective action the underlying, default position, against which the "labor exemption" to antitrust law would then be defined in the New Deal era. ${ }^{7}$ The law of the labor exemption in fact reified the classicists' application of antitrust to worker collective action. It also temporarily held the rule at bay, in service of the new policy project of the New Deal economy, which involved economic co-governance by business, the state, and organized labor. Meanwhile, antitrust began to consolidate into its contemporary neoclassical economic form, disavowing direct consideration of social or moral norms and emphasizing economic efficiency. As evidenced by contemporaneous policy commentary, the labor exemption was viewed by extreme neoclassicists as an unjustified instance of special treatment of labor, a deviation from scientific economic principles.

The deregulation era beginning roughly in the late 1970s began to expose a growing number of workers to antitrust liability, in a reprisal of the Gilded Age version of the antitrust-labor intersection. The body of law-roughly, the neoclassical interpretation of pricefixing - that tentatively comes to apply to these workers, prizes economic efficiency, disavows the social effects (and often even the economic effects) of its antitrust decisions, and certainly disavows moral considerations. To the extent that moral considerations applicable to collective action (such as liberty interests in freedom of association and expression) are enshrined in other areas of law such as the First Amendment, it also keeps those at bay by insisting upon an over-solid distinction between the "economic" and "political"

5. See infra Part II.C.3 (discussing early decisions applying the Sherman Act to workers).

6. See id.

7. See infra Part III (discussing the labor exemption). 
spheres (precisely the distinction called into question by-among other things-the history of antitrust's changing application to labor). Yet, although neoclassical price-fixing law officially disavows moral and social considerations, it in fact relies upon such "extrinsic" considerations in many respects, often tacitly folded into invocations of "legitimate" competition, ${ }^{8}$ and it certainly does so in its relationship to worker collective action. ${ }^{9}$ Because how antitrust is to treat labor is, and always has been, a contingent policy decision involving irreducible normative content, I argue that the rule ought to be revisited in light of the specific moral, political, and economic concerns raised by worker collective action in pursuit of a decent livelihood.

The literature has not previously addressed the development of this rule and its conceptual underpinnings through the various relevant areas of law and eras, although naturally many existing areas of scholarship bear upon the account. The issue of antitrust liability and contemporary independent contractor workers has been flagged in the literature on contingent work, but has not been squarely addressed there. ${ }^{10}$ In its contemporary form, it has been addressed somewhat more squarely by scholars focused on trade, that is, antitrust law and market regulation, particularly as to specific trades or industries. ${ }^{11}$ Some relatively recent work in antitrust economics argues that collective action on the part of certain smaller market actors, including small businesses and independent contractors, ought to be permitted; 12 other work in this area sets out the concept of ruinous competition, which may also have

8. See infra Part IV.A (exploring the normative content of the price-fixing case law).

9. I specifically argue, in Part IV.B, infra, that antitrust imports "extrinsic" normative considerations in the price-fixing doctrine generally, in the operation of what $I$ call the professional privilege, and in the application of, or refusal to apply, First Amendment protection to worker collective action that is not otherwise protected by the labor exemption.

10. See, e.g., Elizabeth Kennedy, Comment, Freedom from Independence: Collective Bargaining Rights for "Dependent Contractors," 26 BERKELEY J. EMP. \& LAB. L. 143 (2005) (noting potential antitrust liability for collective action by independent contractors).

11. The collective economic action of independent contractor physicians in particular has received scholarly attention; the situation is something of a special case, given the complex regulatory structure within which it exists (which may itself create cartel-like benefits). Elizabeth M. Devine, Physical Unionization: A Prescription for Modern Managed Care, 4 QUINNIPIAC HEALTH L.J. 39, 40 (2000).

12. See Warren S. Grimes, The Sherman Act's Unintended Bias Against Lilliputians: Small Players ' Collective Action as a Counter to Relational Market Power, 69 ANTITRUST L.J. 195, 234 (2001) (proposing a limited countervailing power defense for small players' collective action). This argument relies upon a conception of market power whose status in the price-fixing doctrine is currently somewhat tenuous, but which has the potential to be revived, as further explored in Part IV.B.1, infra, and Part IV.B.3, infra. 
application to independent contractor workers. ${ }^{13}$ I bring these insights together with historical considerations regarding the development of both antitrust and pre-New Deal labor regulation.

The bulk of the literature on antitrust and labor generally, meanwhile, dates from during or shortly following the mid-century "normal science" period of the labor exemption, ${ }^{14}$ and is largely defined by its assumptions. In particular, much of this literature is built, either expressly or indirectly, upon assumptions regarding labor unions' size and strength (and relatedly, upon the economic significance of collective bargaining), which no longer hold. 15 As a result, the literature is to a great extent focused upon collective bargaining policy and its antitrust implications, rather than upon unilateral worker collective action, and even the collective bargaining discussions tend to be conditioned by the assumption of labor union size and strength. 16

How antitrust will regulate unilateral worker collective action in the context of contingent work is an especially pressing topic, given its uncertain legal status, its increasing significance in the labor market, ${ }^{17}$ and the significant constraints it is already placing upon these workers and their movements. 18 This problem cannot be obviated by resolving the "misclassification" issue, familiar from labor and employment law, alone. 19

13. See, e.g., KEITH N. HYLTON, ANTITRUST LAW: ECONOMIC THEORY \& COMMON LAW EVOLUTION 94-98 (2003) (comparing the concept of "ruinous competition" between the Sherman Act and common law); Mark Grady, Toward a Positive Economic Theory of Antitrust, 30 ECON. INQUIRY 225 (1992) (discussing the concept of "ruinous competition").

14. See infra Part III.C (discussing the "normal science" of the labor exception).

15. See Ralph K. Winter, Collective Bargaining and Competition: The Application of Antitrust Standards to Union Activities, 73 YALE L.J. 14, 16 (1963) ("[U]nions are far more powerful and strategically entrenched today than at the time of Loewe $v$. Lawlor, and collective bargaining is a significant force shaping the economy."); see also Randall Marks, Labor and Antitrust: Striking a Balance without Balancing, 35 AM. U. L. REV. 699, 701 (1986) (arguing that antitrust does not sufficiently constrain labor). Marks almost exclusively assumes the actions of established labor unions, considers unilateral activity only cursorily, and states "the nonstatutory exemption," which covers collective bargaining, "is most frequently at issue in labor/antitrust cases." Id. Even commentators expressing concern about the diminishing reach of the labor exemption tend to operate on this assumption, concerning themselves primarily with specific doctrinal borderfixing issues. Milton Handler \& William C. Zifchak, Collective Bargaining and the Antitrust Law: The Emasculation of the Labor Exemption, 81 COLUM. L. REV. 459, 460 (1981).

16. Winter, supra note 15; Marks, supra note 15; Handler \& Zifchak, supra note 15; see also Elinor Hoffman, Labor and Antitrust Policy: Drawing a Line of Demarcation, 50 BROOK. L. REV. 1 (1983) (analyzing labor and antitrust policy).

17. See infra Part I.C (discussing potential defendants).

18. See infra Part I.B (discussing antitrust as a barrier to worker collective action).

19. See infra Part I.D (discussing the intersection between labor and employment law). 
But the implications of the question are not limited to contingent workers. The situation of these workers is a test of what antitrust fundamentally says about labor, absent a specific exemption. That exemption is currently rooted in the network of affirmative labor legislation. As the functioning of that affirmative framework arguably declines and as discussion of modifying it or replacing it increases, antitrust's treatment of labor may again become the baseline for those critical conversations-in the same way that it was prior to the New Deal itself, when avoiding antitrust's grasp was one of the main aims of the labor movement. 20 The specific assumption that workers' right to organize for economic betterment is an "exemption" to be bargained for, perhaps by giving up other things, has implications far beyond independent contractor workers.

\section{THE IMPACT OF ANTITRUST ON CONTEMPORARY INDEPENDENT CONTRACTOR WORKERS}

In today's post-New Deal, "deregulation economy," 21 workers are often and increasingly relegated to labor relationships outside formal employment. Collective action by workers who are classified as independent contractors, and who therefore presumptively do not receive the benefit of the labor exemption from antitrust law, may in theory, and has in scattered instances, drawn antitrust scrutiny. As truck drivers, taxi drivers, home health care workers, artists, and others choose to organize in an effort to improve poor pay and working conditions, we may expect to see this issue addressed in the courts if and when one of these movements gains real power. Regardless, the threat of antitrust liability already exercises profound constraints on these workers' ability to organize. Finally, as policy makers and advocates consider new schemes to organize and regulate work that falls outside the bounds of employment, antitrust may function as a limit on the regulatory possibilities (particularly in cases of local initiatives).

20. The labor movement's primary aim, more precisely, was avoiding the judiciary's repression of worker collective action generally, whether accomplished by antitrust or by other bases for issuing injunctions in particular. WILLIAM FORBATH, LAW AND THE SHAPING OF THE AMERICAN LABOR MOVEMENT 128-66 (1991). However, very few of those other bases, many of them explicitly rooted in the older common-law tradition of worker regulation (described in Part II.A.2, infra), have survived to the present day, while antitrust has.

21. I adopt this term to describe the economic policy paradigm that began to replace the New Deal framework starting in roughly the late 1970s. I adopt the term for ease of reference, although this set of policies is often characterized not only by the withdrawal of certain types of regulation but by the extension of other sorts of regulation, often aimed at workers. 


\section{A. The Struggle for Decent Work and Decent Pay as Price-Fixing}

The labor exemption currently immunizes most worker collective action from antitrust liability. Employee status, much discussed in its impact on workers in terms of the receding reach of labor and employment law protections, is also the trigger for extending the grasp of antitrust regulation of workers' autonomous collective action to better their working conditions. In other words, a phenomenon that is commonly understood as exemplifying deregulation actually extends regulation over the conduct of workers even as it withdraws it from the conduct of employers. As a result, individual workers classified as independent contractors may be subject to antitrust prosecution for organizing for decent wages or working conditions under the pricefixing doctrine, regardless of the reasonableness of the wage or the broader social or economic outcome.

Assuming for the moment that the labor exemption does not apply to a given set of independent contractor workers, and that they are not able to prove that they are misclassified employees, the law of price-fixing is likely to govern their concerted action. The modern neoclassical interpretation of antitrust, which mostly still reigns, takes market actors as black boxes: they are just "firms," whether they are massive corporations or a single truck driver. ${ }^{22}$

The relevant cases involving professional workers and "small producers," whose primary business is the selling of their services, are the best predictor of how low-wage independent contractor workers would be treated by antitrust law (and of how "professional" independent contractor workers actually are treated). For the most part, modern courts apply the law of price-fixing to hold that most collective economic action by such actors, particularly if it is aimed at affecting prices or other elements of the bargain and often even if it is not, is illegal price-fixing, unless some specific exception applies. ${ }^{23}$ Neither the reasonableness of the rate nor a net social or economic benefit constitute exceptions. ${ }^{24}$

22. This was not the case in the formative, pre-New Deal period, as described in Part III, infra.

23. See, e.g., Fed. Trade Comm'n v. Superior Court Trial Lawyers Ass'n, 493 U.S. 411, 423 (1990) (collective action by independent lawyers constituted price-fixing); Fed. Trade Comm'n v. Ind. Fed'n of Dentists, 476 U.S. 447 (1986) (collective action by independent dentists); Nat'l Soc'y of Prof'l Eng'rs v. United States, 435 U.S. 679 (1978); Spence v. Se. Alaska Pilots' Ass'n, 789 F. Supp. 1007, 1010 (D. Alaska 1990) (antitrust analysis involving association representing independent contractor pilots).

24. Superior Court Trial Lawyers Ass'n, 493 U.S. at 423-24; Nat'l Soc 'y of Prof'l Eng'rs, 435 U.S. at 695 . 
An especially apt illustration of this theory of liability is the Supreme Court's opinion in Federal Trade Commission v. Superior Court Trial Lawyers Ass ' $n,{ }^{25}$ both because it is a seminal case with respect to pricefixing generally, and because, of all the post-exemption antitrust cases involving professional workers or small producers, it involves facts that very closely resemble classic labor concerted action in which low- or mid-wage independent contractors might engage. In the 1970s and 80s, the District of Columbia had contracted the representation of indigent defendants in the majority of criminal cases to a panel of private attorneys and paid them only $\$ 30$ per hour for in-court time and $\$ 25$ per hour for out-of-court time. The Superior Court Trial Lawyers Association, whose membership was comprised of these panel attorneys, initially tried to persuade the District to raise its members' rates through political delegations and similar efforts. When those efforts were unsuccessful, the attorneys decided they had no choice but to take direct action. They formed a strike committee and agreed to stop taking new panel work until the District agreed to their proposed rate schedule. The strike went off with $90 \%$ participation, and the District acceded to increased rates. ${ }^{26}$

The Federal Trade Commission filed a complaint against the association, alleging an agreement in restraint of trade by "refusing to compete for or accept new appointments under the CJA program[;] . . . a conspiracy to fix prices and to conduct a boycott"; and engaging in "unfair methods of competition." 27 Rejecting the administrative law judge's conclusion that the agreement among the lawyers had not caused economic harm, the FTC decided that the agreement had been a "coercive, concerted refusal to deal" and also caused harm ("substantial anticompetitive effects"). ${ }^{28}$ Accordingly, it entered an order prohibiting any future boycotts: it ordered the lawyers to desist from engaging in any collective withholding of labor in an effort to improve their working conditions. The court of appeal vacated the FTC's cease-and-desist order, holding that the expressive component of the boycott (discussed further in Part IV, infra) warranted closer scrutiny, and in particular that it required a consideration of whether the association possessed

25. Superior Court Trial Lawyers Ass 'n, 493 U.S. at 423-24.

26. Id. at 416 .

27. Id. at 418. Suit was brought under Section 5 of the Federal Trade Commission Act, which gives the agency the authority to bring litigation under the Sherman Act. Id. at 414 (citing Federal Trade Commission Act, ch. 311, § 5, 38 Stat. 717, 719 (1914) (codified as amended at 15 U.S.C. $\S 45(2012)))$.

28. Id. at $419-20$. 
significant market power. ${ }^{29}$ The Supreme Court endorsed the court of appeal's analysis that the "respondents' boycott constituted a classic restraint of trade within the meaning of Section 1 of the Sherman Act," agreeing that "this constriction of supply is the essence of 'price-fixing,' whether it be accomplished by agreeing upon a price ... or by agreeing upon an output, which will increase the price offered." 30 It then insisted that per se treatment was indeed appropriate, and that neither the reasonableness of the price set nor lack of market power on the part of small parties can save anticompetitive behavior from sanction. ${ }^{31}$ Within the modern antitrust jurisprudence, Trial Lawyers is the case whose facts most closely track the sort of worker collective action with which this Article is concerned, and it also represents a certain rigid apex of the Court's neoclassical approach to price-fixing .32

Following Trial Lawyers and these general principles, a court considering labor organizing activity-for example, a strike for higher wages on the part of non-employee truck drivers, artists or art workers, cab drivers, or even day laborers-may not only deny labor and employment law protections to such workers, but may impose treble damages or criminal penalties on the workers instead. Although the issue has not been presented to an appellate court (or a trial court making a decision of law), Trial Lawyers is a reasonable predictor of how it may be decided by a court that chooses to double down on the neoclassical approach rather than reconsider it.

\section{B. An Object Lesson in the Revival of Antitrust as a Bar to Worker Collective Action}

The grassroots movement of port truck drivers in the deregulation era, aimed at improving poor pay and working conditions, drew significant antitrust scrutiny that in turn shaped that movement. This example illustrates the significant obstacle antitrust poses to workers classified as independent contractors who organize to improve their pay and working conditions.

Deregulation-era trucking is characterized by what Michael Belzer calls the labor market paradox: perennial shortages of skilled drivers, coupled with rock-bottom wages and poor working conditions. ${ }^{33}$

29. Id. at 420 .

30. Id. at 423.

31. Id. at 423-24; see also infra Part IV.B.3 (discussing the First Amendment aspects of the Court's analysis).

32. See infra Part IV.B.3 (discussing the First Amendment implications of antitrust law).

33. Michael Belzer, SWEATSHOPS ON WheElS: WinNERS AND LOSERS IN TRUCKING 
Deregulation economic policy has been the apparent cause. ${ }^{34}$ Returns on equity in trucking, particularly in the truckload market, ${ }^{35}$ were not high to begin with; post-deregulation, one might argue that they are actually below cost in the economic sense. ${ }^{36}$ Employers thus often are forced to cut wages below what they would like, and below what they know is required to attract or keep skilled drivers. Drivers in the truckload market, which includes port truck drivers, typically earn pay in the minimum wage range and work extremely long hours. ${ }^{37}$

Port truck drivers in the deregulation era began organizing, both among themselves and in coordination. with established labor organizations, as early as the late 1980 s, in response to the extremely poor working conditions that ensued from deregulation of the trucking industry. The following decade and a half were marked with numerous

DEREGULATION 151-54 (2000) (defining the labor market paradox).

34. Belzer's description of the labor market effects of deregulation policy can be summarized by saying that numerous established firms quickly went out of business, that many new (nonunion) firms entered the market, and that intense price competition forced wages lower and lower. In the early 1980's, in the wake of the Motor Carrier Act, around half of the Class I and Class II general freight carriers, most of them union, went out of business. At the same time, many new non-union carriers registered with the Department of Transportation. But these changes did not happen evenly across the trucking industry. The market largely fractured along TL/LTL ("truckload" and "less-than-truckload") lines, which had not been its prior organizing principle. Surviving firms in the general freight market - the prior biggest carriers-largely shed their TL business, and grew hugely within the LTL sector, taking up the space left by smaller carriers that had left the market. These firms included for example United Parcel Service ("UPS"), which remained union and largely mid-wage. The general freight market consequently concentrated five-fold. Meanwhile, the earlier peripheral TL-only market exploded, seeing the vast majority of the new entrants while also seeing competition, particularly price competition, increase sharply. Id. at $41-42$.

35. The contrast is to the LTL market (e.g., the UPS and Federal Express ("FedEx")). Id. at 202, 204.

36. $C f$. id. at 202 (suggesting that post-deregulation trucking might be a perfect market in the context of orthodox economic theory, in the sense that profits approach zero). However, it might be more accurate to say that profits typically dip below zero when one considers them not in the accounting sense (net of revenue and out-of-pocket costs), but in the economic sense (net of revenue, out-of-pocket costs, and the opportunity cost of capital). HYLTON, supra note 13, at 94 98 (2003). The latter would explain the transitoriness of many port trucking firms, and the niche character of many that have any lasting power at all, enabled by idiosyncratic factors (e.g., special deals, sometimes through family connections, with certain shippers; existence of other operational arms that subsidize the port trucking operations; personal commitment of individual owners or owning families who did well before deregulation). Id.

37. As of 2000 , average real wages in trucking were back at late 1950 's levels. BELZER, supra note 33, at 38. But this statistic belies the true decline, for unlike in the late 1950's, when the industry had not yet fractured into TL and LTL sectors and was more centralized, generally speaking, the current market is characterized by very high wage differentials between these two subsectors. Id. TL truck drivers, including port truck drivers, thus earn close to minimum wage, if not less. Drivers as a rule also work extremely long hours, raising serious health and safety issues. Id. at 152 . 
strikes over issues relating to pay and working conditions, including but not limited to: the failure to account, in pay rates, for spikes in fuel prices; failure to compensate long periods of waiting at port terminals; and numerous safety issues. ${ }^{38}$ The International Brotherhood of Teamsters was intermittently involved in driver organizing during this period, particularly in Los Angeles and Miami, but most of the concerted action was led by independent drivers' organizations. ${ }^{39}$

A number of these actions drew regulatory scrutiny and lawsuits. The United Container Movers Association ("UCMA") was a grassroots, independent drivers' association with some strength, at a minimum, in, Baltimore, Charleston, Seattle, and Savannah. UCMA and its worker leadership found itself as the target of a federal investigation by the Clinton-era Federal Trade Commission, for price-fixing as a result of their organizing toward a union and as a result of work stoppages over low pay and long, uncompensated wait times at ports. The FTC went so far as to serve several drivers, who stated that they were working " 18 hours a day for less than the minimum wage just to make the payments on our trucks and put food on the table" with subpoenas to testify as to their role in a possible price-fixing conspiracy. 40 Some time later, the Support Trucking Group, another independent drivers' association based in Miami, engaged in concerted action over low wages, equipment safety issues, and wait time. It, together with numerous individual truck drivers, was hit with lawsuits from multiple entities, including port terminal operators and Miami-Dade County itself. 41

38. Interview with Jon Zerolnick, Research Dir., L.A. All. for a New Econ. (Aug. 22, 2014) (interview notes on file with the author); Interview with Jon Zerolnick, Research Dir., L.A. All. for a New Econ. (August 3, 2015) (interview notes on file with the author); see RUTH MILLIKEN, L.A. STORY: IMMIGRANT WORKERS AND THE FUTURE OF THE U.S. LABOR MOVEMENT 178-84 (2006) (describing the grassroots, self-starting character of port truck driver organizing in the 1980's and 1990's).

39. MILLIKEN, supra note 38, 178-84; Interview with John Canham-Clyne, Former Dir., Ports Campaign, Change to Win (May 28, 2014) (interview notes on file with the author); Interview with Michael Manley, Staff Attorney, Int'l Bhd. of Teamsters (January 8, 2015) (interview notes on file with the author).

40. Bill Mongelluzzo, Operators Seek to Organize, J. OF CoM. (Dec. 1, 1999, 7:00 PM), http://www.joc.com/operators-seek-organize_19991201.html; see also Rip Watson, Container Haulers Seek to Unionize, J. OF COM. (Sept. 12, 1999, 8:00 PM), http:/www.joc.com/containerhaulers-seek-unionize_19990912.html; Mark Gordon, Truckers Union Boss Ordered to Testify , FLA. TIMES UNION (Dec. 4, 1999), http://jacksonville.com/tu-online/stories/120499/bus_1E1FTC .html.

41. Complaint for Antitrust Violations at 1-2, Miami-Dade Cty. v. Support Trucking Grp., No. 04-cv-21687, 2004 WL 2868811 (S.D. Fla. 2004) ("This case arises out of a massive conspiracy... with the purpose and effect of an attempt to monopolize, to fix prices and to commit other unlawful practices designed to inflate the prices of trucking services provided by 
These actions, while they did not go to verdict or result in decisions of law, ${ }^{42}$ profoundly shaped the course of organizing in this industry. The constantly looming specter of antitrust liability powerfully structured the strategy that port truck drivers pursued in their attempt to improve their working conditions and to gain a collective voice in the workplace-particularly once the drivers' efforts were coordinated into a comprehensive national campaign. ${ }^{43}$ The founding director of that campaign observed: "[The threat of antitrust liability] was one of the three or four major strategic factors in virtually everything that we did. It was part of our checklist. The specter of antitrust liability has significantly suppressed drivers' ability to take collective action to change their economic circumstances." 44 The counsel to the campaign noted that the campaign was extremely cautious about worker collective action on antitrust grounds in its early years, observing: "Apart from the merits and whether damages were recovered, the sheer cost of defending such an action would have been sufficient to shut the campaign down." 45

More recently, when an independent group of port truck drivers in Oakland, California engaged in an episode of collective action (regarding pay rates, surcharges, and uncompensated wait time), their attorney expressed his view that had the movement gained power, they would be likely to face antitrust scrutiny. 46 One driver spoke of the drivers' aspiration to workers' association regardless of employee status, ${ }^{47}$ which antitrust might view as an illegal cartel.

non-union truckers for the movement of goods into and out of the Port of Miami."); Port of Miami Terminal Operating Co. v. Support Trucking, No. 04-cv-21703, 2004 WL 2868838 (S.D. Fla. 2004); Antillean Marine Shipping Corp. v. Various Indep. Owners \& Operators of Indep. Trucking Cos., No. 04-cv-22530, 2004 WL 2875072 (S.D. Fla 2004); Universal Maritime Serv. Corp. v. Support Trucking Grp., Nos. 04-cv-21687, 04-cv-21688, and 04-cv-21703, 2004 WL 2868849 (S.D. Fla. 2004).

42. While it is generally quite difficult to positively determine whether a settlement was reached from docket records alone, a reasonable inference is that the prospect of defending such a lawsuit, which individual low-income or middle-income defendants are not in a position to do, prompted the result desired by plaintiffs in many of these cases: an end to the collective action, and economic capitulation to the plaintiffs' terms.

43. These efforts were largely consolidated into a nationally organized campaign when Change to Win, a coalition of organizing-oriented labor unions, launched its port trucking campaign in 2006. Interview with John Canham-Clyne, supra note 39.

44. Id.

45. Interview with Michael Manley, supra note 39.

46. Interview with Dan Siegel, Partner, Siegel \& Yee (December 23, 2013) (interview notes on file with the author).

47. Interview with Frank Adams, Port Truck Driver \& Former Comm. Member, Port of Oakland Truckers Ass'n (December 23,2013) (interview notes on file with the author). 
Similarly, the threat of antitrust liability may be a formidable barrier to concerted worker action to improve or change working conditions in other industries with large concentrations of independent contractor workers, including other sectors of the trucking industry. Some such industries that have seen active organizing include taxi drivers, ${ }^{48}$ and home health care and child care providers. ${ }^{49}$ In both cases, there have been hints of the antitrust law apparatus being deployed against worker organizing, or hints that could it be so deployed. In the case of home health care worker organizing, the FTC has in the past expressly taken a position against a collective bargaining scheme for such workers, noting that it would "require that private parties engage in conduct that normally would be deemed per se violations of federal antitrust law, including price fixing between competitors." 50 The threat can also be glimpsed in lawsuits initiated in reaction to grassroots collective action by workers outside formal organizing campaigns. A comprehensive search of antitrust actions filed between 2000 and 2014 revealed additional instances of actual litigation targeting collective action by workers outside formal organizing campaigns, including grassroots actions by low-paid truck drivers in other sub-sectors that were met with antitrust prosecution. ${ }^{51}$ Anecdotal evidence-and a reasonable

48. Veena Dubal, Wage Slave or Entrepreneur?: Contesting the Dualism of Legal Worker Identities (2015) (unpublished manuscript) (on file with the Loyola University Chicago School of Law Journal); see also BIJU MATHEW, TAXI! CABS AND CAPITALISM IN NEW YORK CITY (2008).

49. See Peggie R. Smith, The Publicization of Home-Based Care Work in State Labor Law, 92 MINN. L. REV. 1390, 1391 (2008) (noting the prevalence of the independent contractor form in home health care work and describing active organizing among such workers); Peggie R. Smith, Welfare, Child Care, and the People Who Care: Union Representation of Family Child Care Providers, 55 U. KAN. L. REV. 321, 359 (2006) (noting that the recent successful organizing efforts among such workers have been premised on the state action exemption to antitrust law, where the state assumes the role of employer-of-record). The state action exemption, of course, requires the political cooperation of a state entity together with an industry whose structure would allow for such an approach.

50. FTC Staff Comment to the Hon. William J. Seitz Concerning Ohio Exec. Order No. $2007-$ 23S to Establish Collective Bargaining for Home Health Care Workers (Feb. 14, 2008). This is in line with the FTC's general orientation toward health care providers, including doctors. In the case of taxi drivers, while the FTC has not addressed worker organizing directly, it has taken an active interest in the taxi industry generally that, given the agency's general operating principles, may have implications for worker organizing and in particular for any cooperative scheme that resembles collective bargaining.

51. At a minimum, the actions involving workers pursuing concerted action, excluding lawsuits against port truck drivers and driver associations, include: Complaint at 1-2, Siboney Contracting Co. v. Owners Ass'n of Palm Beach \& Broward Cty., No. 9:00-cv-08149-ASG (S.D. Fla. 2000) (indicating that the plaintiff was a corporation that "act[ed] as a broker of rock and aggregate materials for a variety of road and building projects, and... the [i]ndividual [d] efendants are independent truck owner-operators who are members of the Association and 
inference based on the available evidence-suggests that there have been additional threats to sue drawn by such scattered worker actions, beyond what can be found in official court records. The seriousness of the threat is intensified in cases of nontraditional organizing, because some exceptions likely protect workers who are also seeking employee status or who are organizing in concert with an established labor organization that already has a sectoral presence representing employees. 52

\section{Universe of Potential Defendants}

Although difficult to measure with precision, independent contractor workers have been estimated at somewhere between $6-7 \%$ of the overall work force.53 The generally accepted view is that this proportion is increasing. ${ }^{54}$ Independent contractors are spread widely in the type of work they perform, the amounts they earn, and their educational and class backgrounds. There are independent contractors in almost every trade, including the professional trades, and also in almost every type of manufacturing industry that allows for piecework. For purposes of this Section, I refer to workers as independent contractors when their employers classify them as such - putting aside the question, for the moment, whether this would be the accurate legal classification if tested.

We may view the workers we have in mind as comprising three shades on a spectrum with imprecise and permeable borders. First,

believed to be leaders of the Association" and alleged a coordinated work stoppage aimed at a $15 \%$ pay rate increase due to a spike in fuel prices); Verified Complaint at 3,10, Horizon Lines of P.R., Inc. v. Asociacion de Camioneros de Arrastre de P.R., Inc., No. 3:05-cv-01801-PG (D.P.R. 2005) (alleging that an independent drivers' association conducted a classic work stoppage to increase rates); Verified Complaint at 1,3, HN1 Therapy Network of P.R., LLC v. Asociacion Puertoriquena de Fisioterapia, Inc., No. 03:10-cv-1404 (D.P.R. 2010) (identifying a classic group boycott by physical therapists); Verified Complaint at 12, Humana Health Plans of P.R., Inc. v. Juan L. Vilaro, No. 3:12-cv-1445 (D.P.R. 2012) (claiming concerted price-fixing and boycotting by physicians). Numerous instances of lawsuits against small producers who may also be considered workers are excluded from this list.

52. See infra Part II.C.2.b (describing legal arguments that may protect some organizing among independent contractor workers from antitrust scrutiny).

53. Peter H. Cappelli \& J.R. Keller, A Study of the Extent and Potential Causes of Alternative Employment Arrangements, 66 INDUS. \& LAB. REL. REV. 874, 890 (2013).

54. Noah D. Zatz, Working Beyond the Reach or Grasp of Employment Law, in THE GLOVESOFF ECONOMY: WORKPLACE STANDARDS AT THE BOTTOM OF AMERICA'S LABOR MARKET 31, 35-36 (Annette Bernhardt et al. eds., 2008); see U.S. Gov'T ACCOUNTABILITY OFF., GAO-15168R, CONTINGENT WORKFORCE 7 (2015) (noting that despite the difficulties in ascertaining a clear definition of contingent workers, data suggests that there are millions of contingent workers in the market). 
there are people who many in ordinary parlance might not even call "workers," but whom I choose to include in this spectrum because their income derives primarily from their personal labor, that is, from services that they personally perform, rather than from other people's labor or from capital investment. Included within this shade of the spectrum are independent doctors, lawyers, engineers, dentists, and other professionals, who are not employed by someone else and who either have their own small storefront or are self-employed on paper but work in, and for, larger facilities. These people typically have some kind of professional degree or certification, earn middle to high incomes, and are members of the professional social class. While they may employ an administrative or support employee, they personally provide the core services performed by their enterprise. 55

A second set of workers who are often classified as independent contractors, we might dub "soft professionals"-they generally do not have a formal professional degree and may or may not identify with and be considered part of the professional social class, but they have considerable expertise in a relatively specialized field of work, are not as easily individually replaceable as low-wage workers, and generally earn middle incomes. This set of workers may labor in informational technology; in the entertainment industry, particularly pre- and postproduction; repair and construction (electricians and plumbers); and the beauty, massage, and personal care industries.

A third sizable set of workers classified as independent contractors have relatively little formal education (or are unable to take advantage of it in the labor market, due to migration across national borders or other factors), may be considered and consider themselves working class, are relatively easily replaceable by employers on an individual level, and earn low wages. Many people in this category work as truck drivers, taxi drivers or drivers for app-based ride-providing services, laborers in building construction, in home healthcare, and as casual or day laborers. ${ }^{56}$

55. This category of workers may receive softer antitrust scrutiny. See infra Part IV.B.2. Under this scheme, a lawyer or doctor who is no one's employee could obviously be classified as primarily a worker or primarily a business owner, and the classification would depend upon the number of production (as opposed to administrative) employees she has, and the proportion of the time she spends on (and the income she derives from) core services personally performed by her (engaging in lawyering or doctoring work), versus her ownership over and management of others' income-earning labor (overseeing associates' work, investing assets, etc.). Nothing in the argument of this Article relies upon precisely demarcating that line, although the general factors that would determine its location are useful to have in mind.

56. Plainly, there is overlap at each of these borders. For example, many laboring in the 
Finally, small commodity producers who rely in large part on personal labor and lack market power should also be provisionally included in the universe. Of especial historical importance are small farmers, whose livelihoods were greatly affected by the concentrations of economic power that antitrust originally sought to address and who participated in historic alliances with labor organizations to address their economic conditions. ${ }^{57}$

Any type of collective action aimed at improving pay rates or working conditions might expose the groups of workers and economic actors just described 58 to antitrust liability. This rule, I aim to show in the balance of this Article, is a powerful bludgeon with shaky foundations.

\section{Intersection with Work Law}

It is well known that in the contemporary landscape of labor and employment law, the question "who is an employee?" is an increasingly dominant one, given the growth of "contingent labor" in the workforce and the economy. Contingent labor encompasses the various mechanisms by which the traditional employment relationship, which is to a great extent presupposed by extant work law, is attenuated by the employer of labor: subcontracting, temporary work arrangements, and retaining workers as "independent contractors" rather than employees. Each of these arrangements abridges the reach of work law, but none so completely as the independent contractor arrangement, which purports to nullify the employment relation altogether. 59

Workers and worker advocates have thus sought to re-establish the reach of extant work law through the use of legal doctrines and strategies whose contention is that although the new work arrangement may not look like the traditional employment relationship in some superficial respects, it is functionally equivalent to employment. Misclassification refers to the contention that despite the nomenclature adopted by the employer, a particular work arrangement meets the legal test for the employer-employee relationship already contained in the

beauty and personal care industries are low-wage workers, and may earn less than many independent contractor truck drivers.

57. See infra Part II.B (discussing origins of antitrust).

58. While this Article often focuses primarily on low-wage workers, many of its conclusions are generalizable to the other groups of workers and economic actors as well. In future work, I will more directly address the various considerations that might apply to regulating collective action among the groups.

59. Zatz, supra note 54 , at 34-36, 44-45. 
law. The central, but not only, factors in this determination relate to the level of control that the putative employer exerts over the work performed and the operations of which the work is a part. ${ }^{60}$ Another set of factors applicable under many of the tests for employment status takes into account the "economic realities" of the work relationship, which are mainly indicia of the relative power of the two parties to set the terms and conditions of the work performed.61 Because employment status is the threshold question for various regulatory schemes, a variety of definitions and tests apply, and a worker might in theory be considered an employee for purposes of a certain statute and a contractor for another. ${ }^{62}$

The misclassification strategy, however, is not sufficient to dispose of the "independent contractor question." There are practical, factual, and doctrinal reasons for this. As an initial matter, there are the extremely significant practical limitations that attend regulatory enforcement as well as private litigation in terms of both resources and delay, which constrain workers' ability to establish employee status even where it is almost certainly the proper legal conclusion. ${ }^{63}$ Beyond this, employers possess a great deal of power to unilaterally dictate the very factual conditions that determine whether the worker is legally an employee. Indeed, a typical response to misclassification litigation is for employers to adjust operations and the conditions of work so that employee status is again thrown into question and so that they may continue to classify workers as independent contractors under color of law. This point has been made generally by Noah Zatz; ${ }^{64}$ by Julia Tomassetti in the specific context of the FedEx litigation, one of the most significant episodes of

\footnotetext{
60. Id. at 35 .

61. Id.

62. Id.; see also Marc Linder, Dependent and Independent Contractors in Recent U.S. Labor Law: An Ambiguous Dichotomy Rooted in Simulated Statutory Purposelessness, 21 CoMP. LAB. L. \& POLICY J. 187, 187 (1999) (noting that the application of hundreds of statutes and regulations hinge on employee status).
}

63. See generally Scott Cummings, Preemptive Strike: Law in the Campaign for Clean Trucks, 4 UC IRVINE L.R. 939, 1130-40 (describing how these obstacles have manifested in a concrete instance, in the port trucking industry). As Cummings notes, "[ $t]$ he path was not easy. In an industry of hundreds of small companies, misclassification litigation was necessarily a piecemeal approach"; the strategy was dependent upon private firms willing to take a financial risk on fees, and even a successful case would not compel reclassification. Id. at 1131-32. For this and other reasons, misclassification litigation was the campaign's "Plan C." Id. at 1134.

64. See Noah D. Zatz, Beyond Misclassification: Tackling the Independent Contractor Problem Without Redefining Employment, 26 A.B.A. J. LAB. \& EMP. L. 279, 288-89 (2011) (critiquing the "static view" of misclassification, which ignores both employers' fundamental control over the facts that determine employee status and the role of law in employers' choices). 
misclassification litigation in the United States; 65 and by Scott Cummings in the context of the port truck drivers' movement. ${ }^{66}$

Moreover, employer response aside, many low-wage workers may not meet the legal test for employee status even under current conditions. This may turn out to be true in segment of the "gig economy," as Uber, Lyft, and other app-based labor brokering services are sometimes called; even courts are beginning to comment on the potential limitations of the existing legal framework for determining workers' status under changing conditions. ${ }^{67}$ These facts are also acknowledged in the academic literature as forming the basis for various proposals that would go beyond the traditional employee and independent contractor distinction. 68 Finally, many non-employee workers have chosen not to contest their independent contractor status despite engaging in organizing activity. Notable examples are groups of taxi drivers ${ }^{69}$ and of artists and art handlers. ${ }^{70}$ In either case, we are

65. Julia Tomassetti, From Hierarchies to Markets: FedEx Drivers and the Work Contract as Institutional Marker, 19 LEWIS \& CLARK L.R. (forthcoming 2016).

66. Cummings, supra note 63, at 1132 (noting that in the context of the port trucking campaign, "[e]ven successful cases ... often had the effect of simply making companies more stringent about following the independent-contractor rules"). Cummings further states that "industry lawyers conducted trainings ... [o]ne such update recommended that companies 'DO NOT Use a Driver Handbook that looks like an employee manual,' or require a driver to 'wear a company logo,' 'paint the truck a particular color,' or 'display a company ID card"'). Id. at 1138.

67. Judge Chen, in denying Uber's motion for summary judgment in the currently pending, high-profile wage and hour class action brought by its drivers, stated explicitly:

The application of the traditional test of employment-a test which evolved under an economic model very different from the new "sharing economy"-- to Uber's business model creates significant challenges.... It may be that the legislature or appellate courts may eventually refine or revise [the Borello] test in the context of the new economy. It is conceivable that the legislature would enact rules particular to the new so-called "sharing economy."

O'Connor v. Uber Techs., Inc., 82 F. Supp. 3d 1133, 1153 (N.D. Cal. 2015).

68. These include proposals to regulate "dependent contractors" or to divorce many of the benefits traditionally associated with employment from that status and to make them available on some other basis instead. Linder, supra note 62; see also Richard R. Carlson, Why the Law Still Can't Tell an Employee When it Sees One and Why it Ought to Stop Trying, 22 BerKELEY J. EMP. \& LAB. L. 295, 301 (2001) (proposing "an approach to statutory coverage based on the character of the transactions between the parties instead of the status of the parties").

69. Dubal, supra note 48, at 50-56 (regarding San Francisco taxi workers); Interview with Aaron Chappell, Campaign Manager, Org. Dep't, AFL-CIO (July 17, 2015) (regarding drivers organized with the National Taxi Workers Alliance) (interview notes on file with the author).

70. See, e.g., WORKING ARTISTS \& GREATER ECON. (W.A.G.E.), http://www.wageforwork. com (last visited Mar. 22, 2016) (noting the fair-pay certification scheme of W.A.G.E); ART HANDLERS ALL. N.Y., http://www.arthandlersalliance.org/ (last visited Mar. 22, 2016) (noting the organizing efforts of the Art Handlers Alliance of New York); see also Interview with Steve Sewell, Art Handlers All. of N.Y. (Oct. 26, 2015) (interview notes on file with the author). 
talking about workers who sell their personal labor, earn relatively low pay for that labor, and are price-takers in the market. ${ }^{71}$

Part I.B, supra, discussed antitrust liability for unilateral worker collective action. In addition, any regulatory scheme that aims to address collective action by such workers in anything but a purely punitive manner, or aims to provide for minimum working standards, will also come up against the outer limits imposed by antitrust. As the organizing efforts of freelancers, independent contractors, and gig economy workers continue to gain momentum, we can expect to see such proposed schemes. Members of the New York City Council have recently stated that they are currently developing this type of regulatory scheme, prompted by the efforts of the Freelancers Union and other organizing groups. ${ }^{72}$ The City of Seattle recently enacted an ordinance granting collective bargaining rights to drivers for taxicab, limo, and "transportation network companies" (encompassing Uber, Lyft and other companies in the on-demand sector) who are classified as independent contractors rather than employees. 73 Local regulation, as such schemes are likely to be, will probably face federal preemption lawsuits not only under the "NLRA,"74 but also under antitrust.75

A corollary of the main point of this Article is thus that "fixing" misclassification will not obviate the problem of non-employee workers and antitrust liability, a problem that is likely to become more pressing as freelance work becomes increasingly prevalent. To hope that tinkering at the surface with the current legal classifications of workers can, alone, suffice to solve the problem I am posing, is to ignore the fundamental ways in which the underlying structure of antitrust law's

71. There are many reasons, explored in the balance of this Article, not to expose such workers to antitrust liability for collective action; for the present purpose, I wish to establish simply that "misclassification" does not, as a factual matter, obviate the issue.

72. Samar Khurshid, City Council Developing New Protections for Workers in 'Gig' Economy, GOTHAM GAZETTE (Nov. 5, 2015), http:/www.gothamgazette.com/index.php/ government/5971-city-council-developing-new-protections-for-workers-in-gig-economy.

73. SEATTLE, Wash., MUN. CODE $\S \S 630.310 .110,6.310 .735$ (2016), http://clerk.seattle.gov/ legislativeItems/Ordinances/Ord_124968.pdf

74. It is worth noting that any preemption suit under the NLRA - which would have to rely upon the contention that the NLRA embodies the congressional judgment to deny organizing rights to non-employees, at least for the most part-would ultimately be parasitic, if not by direct doctrinal path then by conceptual reliance, upon the outer limits set by antitrust, as well. This point should become clearer after considering the argument of Part II, infra, and will also be developed further in future work.

75. Indeed, as this Article was going to print, an industry group (the United States Chamber of Commerce, no less) filed a lawsuit challenging the Seattle ordinance on grounds that it is barred by antitrust law and by the NLRA. The complaint leads with the antitrust challenge. Complaint, Chamber of Commerce v. City of Seattle, No. 2:16-cv-00322 (W.D. Wash., Mar. 3, 2016). 
relationship to labor shapes the current categories in the first place. To be sure, a consideration of that deep relationship ought to lead us eventually to a reconsideration of the current categories. But to start by adjusting the boundaries between "employee" and "non-employee"with the idea that this will obviate the need to consider that deeper relationship-will likely only repeat the mistake that led us to the current situation (Part III, infra). That deeper relationship between antitrust and workers informs everything from the legal consequences of the current categories, to their definitions and borders, to the existential struggles faced by workers who are left out in the cold by them. To understand it, we must perform some conceptual excavation.

\section{Of Markets, Combinations, And Servants: How Antitrust LaW CAME to Punish WORKer COLLeCtive ACTION}

The first federal antitrust statute, the Sherman Act, was not originally intended to apply to worker collective action, and was instead aimed at protecting traditional small American enterprise from the massive business conglomerations that arose over the course of the nineteenth century. Gilded Age courts, however, applied the statute to workers' collective action. Their reasoning merits scrutiny as we analyze a policy that has not only shaped American labor history, but also has contemporary reverberations that are likely to only become louder.

Classicism, which dominated the common law at the time of the Act's passage, emphasized freedom of contract and free agency on the part of market actors, in reaction to the social and regulatory containment of markets that had characterized the prior era. But the classicist project, as to antitrust and workers, was specifically designed to invite regulation of workers' freely chosen actions and contracts, not to deflect it.

Understood as a component of the larger endeavor by the courts to construct a national market, courts' application of the Sherman Act to worker collective action displayed their willingness to subordinate workers' freedom of action, both political and economic, to that project, which was represented by the notion of "free flow of trade" in the cases. That phrase was often used interchangeably with "freedom of contract," not only in the cases applying the Sherman Act to labor, but also in other areas of law that likewise comprised the project of constructing the national market. Yet the distinction between the two concepts is made evident in the Sherman Act labor cases, because the application of the Act could not be justified on freedom of contract grounds, and instead required the justification involving the "free flow of trade." 
While classicists argued that the Sherman Act ought to be extended to workers on grounds of parity-because business was already subject to it - the fact is that the will of business owners was never made to bend to the "free flow of trade" in the way that the will of workers was. An act and an omission together accomplished this: the judge-made "corporate exemption," an analogue of which workers never enjoyed, and the relative lack of enforcement of Section 2 of the Act (regulating mergers).

\section{A. Classicist Trade Regulation and Nineteenth-Century Labor Regulation}

The Sherman Act regulates trade and, contentiously, labor. ${ }^{76}$ The statute itself says nothing explicitly about labor or work, is very general in its pronouncements, and invokes concepts ("restraint of trade") that were in flux and transition at the time of its drafting. The forms of trade and labor regulation extant at the time of the passage of the Act are therefore of some relevance in understanding its meaning.

The defining element of classicist trade regulation 77 of the Gilded Age period was its opposition to the sort of economic regulation that had preceded it. Commercial law and trade regulation once looked very different, often functioning to contain markets (rather than police barriers to them). ${ }^{78}$ Moreover, commercial and trade regulation largely existed in a mutually reinforcing relation with the collective action of producers (rather than prohibiting it). ${ }^{79}$ Indeed, the original ancestors of antitrust law date to a time before markets defined economic life: doctrines such as forestalling (prohibiting the buying up of merchandise before it reached the market; for example, buying up crops still in the

76. It regulated labor directly from shortly after its passage until the New Deal. It continued to regulate labor indirectly throughout the New Deal period, and is likely to exert increasing direct and indirect effects on workers in our current era.

77. My use of the term "classicism" is drawn from the work of antitrust scholar Herbert Hovenkamp. However, my use of the term herein is somewhat broader and less historically specific: I mean to include the overall approach to economic regulation that had freedom of contract and free trade as its governing ideals, which means I may characterize some decisions and commentary as classicist when Hovenkamp would not do so.

78. Herbert Hovenkamp, The Sherman Act and the Classical Theory of Competition, 74 IowA L. REV. 1019, 1021 (1989); see also HYLTON, supra note 13, at 32 (noting that while today courts aim to enhance competition, "early market interference statutes served largely to suppress competition").

79. Gary Richardson, A Tale of Two Theories: Monopolies and Craft Guilds in Medieval England and Modern Imagination, 23 J. HIST. ECON. THOUGHT 217, 233 (2001) (showing that in some cases the edicts of economic collectives such as guilds were actually continuous with, and even evolved into, local trade regulation). 
field), engrossing (prohibiting the stockpiling of merchandise in order to raise prices), and regrating (prohibiting the buying and reselling of merchandise in the same or neighboring markets after prices rise). 80 Modern commentators, steeped in neoclassicism, may have a tendency to see these doctrines as motivated by an anti-competitive policy. ${ }^{81}$ But these policies likely had both anti-competitive and pro-competitive effects. A better description might be that they were motivated by something other than the contemporary idea of competition altogetherwhich did not, after all, exist yet. They simply defined and regulated trade and markets in the interest of social welfare, and that conception of welfare was not particularly tied to the idea of market competition. 82

Meanwhile, although the hierarchical and coercive character of labor regulation inherited from the feudal era was a constant both prior to and during the Gilded Age, it is likely that at least in the United States, many more working people came under its purview during the Gilded Age. ${ }^{83}$ In other words, prior to the transformation in which the national market came to define economic life ${ }^{84}$ and the modern business corporation replaced its almost unrecognizable pre-market ancestor, 85 many working people labored outside the context of wage labor, and thus outside master and servant law. Many working people thus

80. HYLTON, supra note 13, at 32; Richardson, supra note 79, at 218 .

81. "The main difference between these early statutes and the Sherman Act is that courts interpret federal antitrust law today as aiming to enhance competition, while the early market interference statutes served largely to suppress competition." HYLTON, supra note 13, at 32.

82. See Richardson, supra note 79 , at 230 (recognizing that "trading regulations" functioned to help ensure that economic activity was "in the general interest"); KARL POLANYI, THE GREAT TRANSFORMATION: THE POLITICAL AND ECONOMIC ORIGINS OF OUR TIME 45-58 (2001) (arguing that all economic regulation prior to the emergence of market economies was embedded in that particular society's conception of the overall social good, rather than existing in a separate economic sphere in which market competition was the reigning ideal).

83. See infra Part II.A.2.

84. See generally RICHARD FRANKLIN BENSEL, THE POLITICAL ECONOMY OF AMERICAN INDUSTRIALIZATION, 1877-1900 (2000) (describing the political construction of the national market).

85. Their ancestor, the guild, combined the activities of both commerce and labor. As a legal category, very early corporations were thus simply one species of the cooperative organizations that economist Gary Richardson calls "occupational cooperatives." Gary Richardson \& Michael McBride, Religion, Longevity, and Cooperation: The Case of the Craft Guild, 71 J. ECON. BEHAV. \& ORG. 172, 174 (2009). In the United States, "[p]rior to the 1840s, the character and organization of American business enterprise was predominantly small-scale," with "relatively low levels of capitalization." CHRISTOPHER L. TOMLINS, THE STATE AND THE UNIONS: LABOR RELATIONS, LAW, AND THE ORGANIZED LABOR MOVEMENT IN AMERICA, 1880-1960, at 17 (1985); see also HERBERT HOVENKAMP, ENTERPRISE AND AMERICAN LAW, 1836-1937, at 13 (1991) (describing the pre-classical American business corporation). 
enjoyed a greater level of both legal and economic independence than what became normal in the Gilded Age. 86

As we shall see, these two streams, classicist trade regulation and feudal labor regulation, converged in the application of the Sherman Act to worker collective action. Meanwhile, the surviving minor strain of republicanism, which had animated the Act in the first place, carried forward echoes of the economic regulation that had preceded both the trade and labor regimes of the Gilded Age.

\section{Classicist Trade Regulation}

According to the conventional view, the Sherman Act was continuous with the common law of trade regulation. That body of law was primarily concerned removing the vestiges of pre-market trade regulation to the extent that they placed constraints on the activities of market actors. ${ }^{87}$ Whether the official ideology of freedom of contract and trade, and individual liberty emphasized in the common law, 88 was the source or the mechanism of that economic policy, it was certainly closely bound up with it. At the same time, I contend that the classicist notion of freedom of trade contained a basic equivocation, between the clear liberty-based concept and a more nebulous concept often denoted by the phrase the "free flow of trade." This notion of "free trade" had nothing to do with any person's freedom, but with the unobstructed free flow of commerce. . This second conception comes into full relief in the cases that apply the Sherman Act to labor, ${ }^{89}$ where it actually trumps the freedom of contract interests that would seem to militate in favor of permitting the coordinated actions at issue.

In terms of distinguishing the official ideology of the classicists from that of contemporary "neoclassicists," Herbert Hovenkamp points out that the primary concern of classicism was not competition in the contemporary sense, but rather individual liberty for commercial actors-in particular, freedom of contract. ${ }^{90}$ Classicism's conception of competition was derivative of the basic idea of liberty from constraints. "For [American classicists] as well as the English classicists,

86. Christopher Tomlins, Subordination, Authority, Law: Subjects in Labor History, 47 INT'L LAB. \& WORKING-CLASS HIST. 59, 62-63 (1995) (stating that in its pre-market forms, the work relationship was not "a single form of relationship but ... multiple forms of relationship, some of sanctioned abuse and abasement (those old disciplines), some of temporary and shifting attachment, some of autonomy and self-direction" (emphasis added)).

87. Hovenkamp, supra note 78 , at 1026.

88. Id. at 1021.

89. See infra Part II.B.2.

90. Hovenkamp, supra note 78 , at $\mathbf{1 0 2 1 .}$ 
competition meant both rivalry and freedom from constraints, such as the exclusive privileges so common in the Mercantilist period."91 For them, and even well into the transition to neoclassicism, "competition referred to a theory about liberty and free choice, not to a description of price/cost relationships."92

Price-fixing - the paradigmatic modern anticompetitive activitywas not tortious under the classical common law, much less criminal. 93 One can see why the common law was at best ambivalent: if freely entered, such a contract does not violate individual liberty. "Cartels did not jolt the common lawyer's conscience because no one's freedom was being denied."94 Further, classicism's particular conception of competition, which included competition between actors in adjacent markets (i.e., vertical competition), ${ }^{95}$ made price-fixing more understandable as rational and permissible, self-interested market activity by one market actor (the seller) in competition with another (the buyer), to which the other was free to respond.

Similarly, restraints of trade that prevented entry into a marketrestraints that the classical common law viewed as the primary enemy of "free trade"-were problematic not because they hurt the consumer or distorted the market by decreasing the "natural" number of participants in a particular market, but because they violated the individual economic liberty of the prospective entrant. "The historical concern of the common law of contracts in restraint of trade was coercion, or the elimination of noncontracting parties' freedom to act."96 For this reason, the common law was "obsess[ed] with consideration in cases challenging agreements in restraints of trade," such as non-compete clauses. ${ }^{97}$

In short, classicist principles generally favored commercial actors' freedom to compete, including the freedom to vertically compete-for sellers to compete with buyers, for example. Nevertheless, as we shall see, classicists affirmatively sought, through the mechanism of the Sherman Act, to curb workers' freedom to vertically compete, that is, to curb their freedom to compete with capital by acting collectively to withhold labor upon condition of better wages or working conditions.

91. Id. at 1025 (internal quotation marks omitted).

92. Id.

93. Id. at $1026-29$.

94. Id. at 1027.

95. Id.

96. Id. at 1026 .

97. Id. at 1027. 
To understand this, we require the related but distinct concept of the "free flow of trade," easily mistaken for a synonym of "freedom of trade." The concept itself came into full relief in the Sherman Act labor cases, for that is where it operated independently of freedom of contract.

\section{Labor Regulation in the Gilded Age}

The Sherman Act became the first federal statute regulating labor. The character of the pre-existing regulation of work is relevant to understanding how the Sherman Act came to have that role.

In the late nineteenth century, the employment relation remained within the province of the common-law courts, as the relation between masters and servants had been for hundreds of years, while most other realms of social life were by then the subject of modern statutes created by democratically elected legislators. ${ }^{98}$ This meant not only that the new democratic apparatus of lawmaking was mostly kept apart from the workplace, but also that relatively more conservative judges, rather than relatively more progressive legislators, were the lawmakers in this province. 99 The legal constitution of the employment relation at this time was the great exception to classicism's clarion call of economic freedom; it carried over the hierarchy, with its concomitant restraints on individual freedoms, that had been the defining element of feudal society. 100 At the same time, with the ascendancy of wage labor, many more people and many more economic relationships were brought under its purview. 101

98. See generally KAREN ORREN, BELATED FEUDALISM: LABOR, THE LAW, AND LIBERAL DEVELOPMENT IN THE UNITED STATES 79-91 (1991) (discussing the judicial governance of master and servant); see also id. at 81 (" $[\mathrm{J}]$ udges by their ritual enforcement held up a structure of domination that had existed since time out of mind."); see also FORBATH, supra note 20, at 6 ("Nowhere else among industrial nations did the judiciary hold such sway over labor relations as in nineteenth- and early-twentieth-century America.").

99. See ORREN, supra note 98, at 15-16 ("[T] he substance of relations between employers and employees still was under the ultimate jurisdiction of courts, as was the case in the Middle Ages, and ... the old common-law rules of labor governance had been left standing while other institutions had been changed or dissolved.").

100. Id. at 67 (explaining that while commercial interests came unfettered from earlier constraints, labor remained subject to them: indeed, "commercial interests . . . were prospering on the basis of the ancient labor regime still in place" and "workers continued to be governed by quite different precepts, likewise endorsed as beneficial to what one judge" called the "province of workingmen"); see also id. at 71-79 ("The order of labor").

101. Tomlins, supra note 86 , at 63 ("The eventual reduction of these multiple forms [of the working relationship] to a single form was in good part shaped by the deployment in English and American law of generic rules implementing uniform relations of subjection (master/servant) to pertain between those worked and those for whom they worked."). 
Karen Orren shows that the employment relation in nineteenthcentury America was suffused with substantive rights and obligations that were assigned in part based upon status (as they had been for all sectors of feudal society), and not just based upon the content of freely bargained contracts. ${ }^{102}$ Many of these obligations, moreover, abrogated workers' personal freedoms in various ways. The character of employment law in the late nineteenth century thus involved a kind of subordination that co-existed uneasily with the fact that work is "the prototypical voluntary behavior" on liberalism's own principles. 103

There are numerous examples of these substantive rights and obligations rooted in feudal hierarchy that were still very much alive in nineteenth century American employment law, ${ }^{104}$ but the most salient are those limiting workers' freedom to quit and those limiting collective action to improve working conditions. 105 The tort of enticement dominated the courts' regulation of workers' collective action, and demonstrates the ancient nature of the judicial regulation of labor well into the nineteenth century: that action had remained more or less constant for the six centuries prior. 106 The basic reasoning was that someone who "enticed" workers (servants) away from their work (or "induce[d] him to leave his master"), in this case for the purpose of holding out for higher wages, was liable for damages to the master. 107 Enticement was often the basis for a charge or complaint of conspiracy, and was on occasion used to prosecute concerted work stoppages aimed at conditions such as non-payment of wages. 108

102. See ORREN, supra note 98 , at $68-117$.

103. Id. at 24.

104. To take just one example, the principle of quicquid acquietur servo acquietur dominowhatever is acquired by the servant is acquired by the master-comes down in a direct line from a legal feature of villeinage, that anything acquired by him belonged to his lord. In the United States, it was applied all the way through the late nineteenth century in the "moonlighting" context to allow an employer to recover not only for any hours missed (and, of course, to dismiss the worker) but actually to recover wages earned in the second job. This particularly underlines the personal, not abstract or fungible, nature of the employment relationship, at least in the direction of the duty from employee to employer. Id. at 78-79.

105. The right to quit, which judges generally formally protected within master-servant law, was greatly circumscribed by the "performance of the entire contract" rule (and its interpretation to allow employers to have almost any reason for discharge) for wages due, together with the long span between pay periods. Although technically, employers also could not end the contract without cause, in practice, courts allowed them almost any cause; whereas whether the servant had just cause to leave was largely determined by the opinion of the master. Id. at 84-86.

106. Id. at $122-28$.

107. Id. at 123 .

108. Id. at 124 . 
Drawing upon such common-law materials, the evolving law of labor conspiracies came to authorize injunctions against concerted action in the very late nineteenth century, giving rise to the (in)famous "government by injunction."109 Shifting and variable conceptions of property were instrumental in grounding these labor injunctions. 110 The Sherman Act, once it was applied to worker collective action, became another powerful tool to ground and expand the labor injunction (it also allowed recovery of damages).111 The common-law bases for injunctions and the old law of labor conspiracies died out as the modern employment relation was born with the New Deal. The Sherman Act, meanwhile, only grew in both practical and symbolic prominence. And while the Act's application to labor seemed to be cut short by the New Deal, in truth it merely went underground, whence it continued to exert influence and send up shoots.

\section{B. The Sherman Act and Its Relationship to Labor}

The Sherman Act was not originally intended to apply to the activities of labor unions qua labor unions nor to worker collective action. 112

First, the Act was largely a product of the republicanism that was current among much of the populace, the legislature, and the labor movement in the late nineteenth century; that republicanism was quite inconsistent with the prohibition of workers' collective action to improve their working conditions. Generally speaking, this republicanism supposed that American society promised its members "a basis of real equality" that had "economic and social," not only legal or formal, dimensions. ${ }^{113}$ It has been well documented that American public opinion was constellated against the unprecedented concentrations of capital in the post-Civil War era, and that this opinion

109. See generally FORBATH, supra note 20 , at 59-97. The seminal, near-contemporaneous text that documented the use of the labor injunction (and whose authors went on to become two of the architects of the New Deal framework that succeeded it) was Felix Frankfurter and Nathan Greene's THE LABOR INJUNCTION (1930).

110. BENSEL, supra note 84 , at 342; FORBATH, supra note 20, at 85-88.

111. BENSEL, supra note 84 , at 343 .

112. Cf. Herbert Hovenkamp, Labor Conspiracies in American Law, 1880-1930, 66 TEX. L. REV. 919,951 (1988) (suggesting that the "consensus view" is that the Act was intended to apply to labor).

113. See, e.g., TOMLINS, supra note 85, at 34-35 (1985) (discussing the revolutionary generation's outlook for the future after the newfound liberty and independence brought by the American Revolution). 
cut across party lines. ${ }^{114}$ President Grover Cleveland had this to say in 1888:

As we view the achievements of aggregated capital, we discover the existence of trusts, combinations, and monopolies, while the citizen is struggling far in the rear or is trampled to death beneath an iron heel. Corporations, which should be the carefully restrained creatures of the law and the servants of the people, are fast becoming the people's masters. 115

President Benjamin Harrison echoed him shortly afterward.116 Senator Sherman himself had become an outspoken critic of trusts a few years before. 117 Antitrust was part of the political and legal response to this unprecedented aggregation of economic power. ${ }^{118}$ The republican orientation of the Sherman Act was much more concerned with preserving small, traditional industry and business in the face of the new, large enterprises, than it was with consumer protection, which was likely a minor concern at best. 119 It was even less concerned with abstract ideals of free trade. This is evident in the fact that Senator Sherman was not opposed to tariffs, while the late nineteenth century "advocates of free trade" were. 120 This republicanism was inconsistent

114. Joseph L. Greenslade, Labor Unions and the Sherman Act: Rethinking Labor's Nonstatutory Exemption, 22 LOY. L.A. L. REV. 151, 152-54 (1988); Elinor R. Hoffman, Labor and Antitrust Policy: Drawing a Line of Demarcation, 50 BROOK. L. REV. 1, 9-19 (1983).

115. EARL W. KINTNER, THE LEGISLATIVE HiSTORY OF THE FEDERAL ANTITRUST LAWS AND RELATED STATUTES 58 (1978).

116. Id. at 60 .

117. Notably, the reason we call it antitrust regulation is that the law of corporations was still fairly restrictive; trusts were the comparatively unfettered vehicles chosen by early industrialists to conglomerate investment until the corporate form was "liberalized" and became the primary vehicle of raising investment for commercial activity.

118. See, e.g., TOMLINS, supra note 85, at 29-30 (characterizing them as mostly "symbolic," and describing how antitrust was part of the contemporaneous "debates over the aggregation of economic power").

119. Werner Troesken, The Letters of John Sherman and the Origin of Antitrust, 15 REV. AUSTRIAN ECON. 275, 291 (2002).

Taken as a whole, the Sherman letters undermine the traditional view that consumers lobbied for, and supported, antitrust because the trusts were increasing prices. All of the letters Sherman received regarding antitrust were from small businesses, and only one of these businesses, the John Deere Company, complained about pools and combinations driving up prices. Id.

\section{Id. at 287.}

The belief that reducing tariffs would help solve the trust problem was widely shared by nineteenth century observers and advocates of free trade.... During the same period, Democrats in both the house and senate introduced bills that would have eliminated tariff protections in any industry dominated [by] monopolistic trusts. Senator Sherman, however, continued to support high tariffs and opposed using tariff 
with punishing worker collective action. In fact, some of the core embodiments of republicanism in the nineteenth century involved collective action by workers, ${ }^{121}$ in the craft tradition ${ }^{122}$ and beyond into the more radical tradition of the Knights of Labor. ${ }^{123}$

Second, in addition to this profound inconsistency with the original animating sentiments behind antitrust, the legislative history expressly supports the conclusion that the Sherman Act was not intended to punish worker collective action. Richard Bensel concludes that "one of the clearest themes in the legislative history was the notable reluctance, even opposition, to including labor unions within the act's scope."124 Joseph Greenslade cites the many senators who expressed worry that the bill might be applied to prevent "the laborers of the country... [from] combin[ing] either for the purposes of putting up the price of their labor or securing for themselves a better position in the world," 125 to whom Senator Sherman replied: "combinations of workingmen to promote their interests, promote their welfare, and increase their pay ... are not affected in the slightest degree, nor can they be included in the words or intent of the bill." 126 Legislators' statements during the passage of the later Clayton Act also support this ascription of intent, as they expressed their disbelief that the courts had applied the Sherman Act against combinations of workers. ${ }^{127}$ Attorney General Richard Olney, a former railroad lawyer and certainly not an economic radical, called the application of the Sherman Act to "the combination of laborers known as a strike" a "perversion of a law from the real purpose of its authors." 128

Greenslade also provides a convincing counter-explanation for the main point relied upon by the "consensus view" within antitrust, that the

\footnotetext{
reductions to combat the trusts.

Id.
}

121. William Forbath, Ambiguities of Free Labor in the Gilded Age, 1985 WIS. L. REV. 767, 800-12 (describing "labor's anti-capitalist republicanism" as offering a competing interpretation of republican liberty to the narrow interpretation endorsed by Gilded Age, classicist courts).

122. See generally TOMLINS, supra note 85 , at 32-59.

123. AlEX GOUREVITCH, FROM SLAVERY to THE COOPERATIVE COMMONWEALTH: LABOR AND REPUBLICAN LIBERTY IN THE NINETEENTH CENTURY 98-102 (2015) ("The Knights were the first post-Civil War labor organization open to nearly all workers, including unskilled, black and women workers...." Labor republicans "were united by their use of republican ideas to criticize wage-labor and to present cooperation as an alternative.").

124. BENSEL, supra note 84 , at $342-43$.

125. Greenslade, supra note 114 , at 155 n.30.

126. Id. at 155 n.33.

127. Id. at 160 .

128. 1893 ATT'Y GEN. ANN. REP. Xxvii-Xxviii (internal quotation marks omitted). 
Sherman Act was meant to inhibit worker collective action. He points out that a specific amendment exempting labor was considered but not, in the end, adopted. In fact, Sherman did propose such an amendment to his original bill, and the Senate adopted it. However, statements of the consensus view usually leave out the fact that the Judiciary Committee then rewrote the bill, shifting the emphasis from Sherman's original language, which had focused upon effects on consumer prices, to the idea of restraint of trade.129 When the new bill came out of committee, the same senators who had complained of the possible distortion of the bill to punish "workingmen" were silent, presumably because they did not worry that worker collective action would be considered a restraint of trade. ${ }^{130}$

It would be wrong to read back into these legislators' intent, a century of development in antitrust doctrine and economic theory. Remember that price-fixing was not yet the obvious wrong that it would become with the full transition to neoclassicism. Without express language about consumer prices, it was far from clear what a "restraint of trade" really was; that concept was in massive flux at that time. The fact that the courts went on to define it the way they did cannot be read back into the legislative intent.

Yet the Sherman Act, originally the child of a republicanism that opposed huge conglomerations of capital and sought to protect the small enterprise and artisan of traditional American economic life, soon enough became a weapon against the working people who labored for those new conglomerations. What happened?

\section{Parity: A Bridge from Feudal Labor Regulation to Modern Trade Regulation}

The classicists took on the application of the Sherman Act to punish worker collective political and economic action as an affirmative project, seeking a kind of parity between capital and labor in the Act's application. To be sure, this doctrinal project must be understood in terms of the larger movement in law (deference to business corporations' decision-making) of which it was a part, ${ }^{131}$ and in light of the still-larger policy project that movement served (building the

129. Greenslade, supra note 114 , at $155-56$.

130. Id. at 158 .

131. See, e.g., TomLINS, supra note 85 , at 21-30 (describing the critical role of legal institutions in their "regulation of property rights and promotion of economic development"and, thus, in bringing about an increasing deference to business corporations' decision makingeven and especially against local regulation). 
national market society). ${ }^{132}$ In this Section, I consider how this broader context informed the basic concepts (of freedom of contract and free trade) employed within the cases. I argue that the doctrinal project was deeply embedded in a sense of social hierarchy between buyers of labor and sellers of labor-a hierarchy anchoring control over workers by those who employed them-which was not cognizable on official freedom of contract principles. The method by which classicists achieved this aim contained a kind of double-speak regarding the ascription of moral and legal agency to working people, which then manifested in the early judicial decisions applying the Sherman Act to worker collective action. Even had classicists not expressly invoked this hierarchical and coercive legal tradition, the context of legal subordination of labor in which the idea of parity operated rendered it problematic, if not paradoxical. I contend that these paradoxes rest ultimately upon an equivocation in the meaning of the "freedom" invoked in the jurisprudence.

\section{The Argument from Parity}

Recall that classicist principles favored the freedom to competeincluding the freedom to vertically compete; that is, for actors in adjacent markets to compete. The fact that classicists sought to curb workers' freedom in this regard, that is, to compete with capital by acting collectively to withhold labor upon condition, thus requires explanation. Before any courts addressed the issue, classicists argued in treatises and other publications that there ought to be parity between capital and labor in respect of their freedom to combine in furtherance of their efforts to vertically compete (with consumers, and with labor on capital's part, and with capital on labor's part). ${ }^{133}$ The argument from parity then could be the claim that a particular instance of vertical competition (between sellers of labor and buyers of labor) is unfair, because one side is being subjected to strictures (regarding the ability to exert collective power) that the other is not. In other words, if business is going to be subject to these restrictions, then, out of faimess, labor should be as well. Thus, the classicists were perhaps concerned with horizontal competition only insofar as differential restrictions on

132. See generally BENSEL, supra note 84 , at 289-354 (discussing the construction of the "national market").

133. See Hovenkamp, supra note 112, at 926-32 (describing the common-law treatise tradition's strong bent toward characterizing the law of combinations as treating "labor combinations more favorably than business combinations" and urging that "the public policy toward labor combinations ought to be the same as the policy concerning cartels"). 
combinations to limit that competition affected the balance of power between capital and labor in vertical competition. Prominent lawyer Arthur Eddy wrote:

The object of decisions and laws against combinations being to protect the consumer against maintenance of price at abnormal levels, it would naturally be supposed that both laws and decisions would be directed impartially against combinations of both labor and capital; that no discrimination would be made, since a combination of one may affect prices in exactly the same way as a combination of the other; but so far from there being no discrimination, it is well-settled [that labor combinations are legal while capital combinations are not.] $]^{134}$

Eddy's concern was "fairness" and "impartiality" in the application of a rule, whatever its content, not with furthering the purposes of the rule itself. ${ }^{135}$ Lamenting the application of the "strict" rule of consumer protection to capital while it is not applied to labor, he was moved to comment: "The manifest injustice, not to say absurdity, of this condition of things appeals to every fair-minded man." 136

The assertion of this "unfairness" was arguably made with a presupposition of the very social hierarchy that neutrally applied freedom of contract principles ought to have condemned. In other words, in asserting that antitrust law's failure to punish worker collective action was unfair, classicists betrayed a normative commitment to a hierarchy between workers and employers that should have been anathema to them. Many classicists felt that the balance of power between capital and labor was already tilted in labor's favor. Among the reasons they cited (for the background imbalance of power between capital and labor) was America's supposed labor shortages. ${ }^{137}$ But Hovenkamp also describes a more surprising strain that "dominated" classicist thinking about labor: classicists' concern with

134. ARTHUR EDDY, THE LAW OF COMBINATIONS: CONTRACTS IN RESTRAINT OF TRADE 1331 (1901) (emphasis added).

135. That Eddy, in particular, was not particularly interested in the consumer protection content or purpose of the rule itself is also suggested by, among other things, the fact that he was personally responsible, in his capacity as a corporate lawyer, for organizing the National Carbon Company (out of many previously existing carbon companies), which soon controlled $75 \%$ of the worldwide carbon market, as well as having a key helping hand in the incorporation of several other massive oligopolies. Big Carbon Firms Combine: Three-Fourths of This Industry in the World Included, N.Y. TIMES, Jan. 10, 1899, at 1.

136. EDDY, supra note 134 , at 1331.

137. Hovenkamp, supra note 112, at 930. 
the relative social mobility between the working and owning classes in the United States (as compared, for example, to Europe).

Equally important was the perception of easy worker mobility that dominated most nineteenth century thought: any American laborer could save a little money, borrow from others, and become an entrepreneur himself. As treatise writer Theodore Sedgwick observed as early as 1836, New England laborers could "lay up half their wages" and within a few years they could either "settle as farmers in the new states" or "undertake an independent business in the old." On the other hand, "[i]n Europe, the common rule [was], once a servant, always a servant; once a mechanic, always a mechanic; once a tenant, always a tenant ...."138

Such a "rule" would in fact be a barrier to market entry, a violation of the most fundamental classicist principles. Construing the absence of the rule as an imbalance in labor's favor suggests an underlying commitment to the hierarchical suppression of workers' freedoms as the natural order of things.

Direct reliance upon hierarchy by the classicists aside, there may be enduring reasons to consider the distinctiveness of labor contracts, which might pose problems for a categorical argument from parity. A strong version of this distinctiveness is articulated by theorists from Marx to Polanyi: if labor is a "fictitious commodity" then it is nonsensical to posit an equivalence between its sellers and sellers of actual commodities. 139 However, it is not necessary to embrace the strong version of this critique to see that labor contracts have some distinctive features that might pose problems for a simple-minded argument from parity. The republican tradition, which was associated with the Sherman Act, certainly recognized this distinctiveness. Labor republicans pointed to the hierarchy inherent in labor contracts together with the differentials in both market power and wealth between the parties that came to characterize such contracts, allowing employers to unilaterally set terms. ${ }^{140}$ A growing strand of contemporary labor economics recognizes these same dimensions of distinctiveness. ${ }^{141}$

138. Id. at 931 .

139. POLANYI, supra note 82, at 75 ("Commodities are... objects produced for sale on the market.... But labor, land, and money are obviously not commodities .... Labor is only another name for a human activity which goes with life itself, which in its turn is not produced for sale but for entirely different reasons, nor can that activity be detached from the rest of life, be stored or mobilized ....").

140. GOUREVITCH, supra note 123, at 106-16 (discussing the labor republicans' idea of the distinctiveness of labor contracts: "material domination" grounded in absence of wealth on the 


\section{Implementing Parity in the Courts}

The early wave of antitrust cases that implemented what I have been calling the argument from parity, applying the Sherman Act to regulate and punish worker collective action, relied upon the ambiguity in the meaning of free trade that was mentioned earlier. It is in these cases that the meaning of "free flow of trade" is brought into clear relief, for here (unlike in, for example, the economic due process cases) it operates in logical opposition to freedom of contract rather than in harmony with it. These cases protected the free flow of trade-necessary to the constitution of new markets, particularly the national market-against workers' liberty interests in collective economic and political action with respect to their working conditions and livelihoods. ${ }^{142}$ In doing so, they invoked a long tradition of subordinating workers and their interests to their employers' and to other societal interests, expressly relying upon their status as workers to do so, contrary to what freedom of contract would prescribe. This early interpretation of the Sherman Act was also the bridge to the modern, neoclassicist antitrust framework that would take the application of the Act to labor, absent a specific statutory exemption, for granted.

\section{a. The Workingmen's Amalgamated Case: Three Ambiguous "Evils"}

The story of how the bridge was built begins with a massive general strike in New Orleans that grew primarily out of the desire of drayage drivers ("draymen") and warehouse workers to improve their wages and working conditions. 143 The actions included the coordinated stoppage

part of workers; market power on the part of employers allowing them to unilaterally set terms, namely long hours and low pay; and the hierarchy and control implied by all the contract "left unsaid," requiring the worker to "passively obey the commands of the employer").

141. See, e.g., ALAN MANNING, MONOPSONY IN MOTION (2003) (focusing especially upon differentials in market power and wealth as creating economic inefficiencies).

142. This Subsection focuses primarily on a close reading of the first published decision to apply the Sherman Act in this way, with the aim of demonstrating the continuity with the earlier tradition of labor regulation as well as the ambiguity in the use of the concept "free trade." It is not the only significant decision from the Gilded Age period to apply the Sherman Act against workers. Some other decisions are discussed, though more briefly, infra. Moreover, the same year as Workingmen's Amalgamated, see supra Part II.C.2.a, another federal district court also applied the Sherman Act to worker collective action. However, in that case, what the court considered the special regulatory and factual situation of the railroads (which were presumed to justify greater judicial intervention in labor disputes, through the device of judicial receivership and on the basis of additional statutes specific to the railroads) played a crucial part in the court's reasoning. Waterhouse v. Comer, 55 F. 149, 154 (S.D. Ga. 1893).

143. United States v. Workingmen's Amalgamated Council of New Orleans, 54 F. 994, 995 (E.D. La. 1893); FORBATH, supra note 20, at 71 ("The first application of the Sherman Act to industrial strife occurred in a tumultuous New Orleans longshoremen's strike, which tied up the 
of work (the work, primarily, of transporting goods to and from the Port of New Orleans), public demonstrations, attempting to persuade others to join in the stoppage, and finally, the participation of other workers in the city not directly involved in the transportation of these goods. 144

The relatively brief district court opinion allowed an injunction to be issued against various workers' organizations that had organized the work stoppage and pickets. ${ }^{145}$ The opinion hardly reads as if it were deciding a tremendously significant issue of first impression: namely, whether the new Sherman Act should in principle apply to the collective action of workers to improve their working conditions. Rather, it disposes with that issue as if it were a mere preliminary. ${ }^{146}$ The decision was significant because not only was it the first decision to apply the Sherman Act to worker collective action, but also because the Supreme Court's seal of approval on that extension of the Act, about a decade and a half later, specifically endorsed it. 147

The Louisiana district court stated the primary legal question it was deciding was whether the facts before it were "for the purpose of restraining . . . commerce." 148 In support of the court's conclusion that "there can [not] be any question but that the combination of defendants was in restraint of commerce,"149 we can glimpse three possible wrongs: (1) coercion, such as violence or intimidation, directed by some workers or combinations of workers toward other workers with the aim of preventing them from working; (2) the simple fact of "slowing" or "stagnating" commerce, by whatever means and for whatever end; and finally, (3) the individually voluntary and coordinated decisions by numerous workers to cease (or slow) their work, conditioned upon some improvement in the terms and conditions of work for all. Of these, the last is the only one that may plausibly translate into the contemporary antitrust framework: an intentional constriction of supply aimed at influencing price (or at influencing other terms of the bargain, which neoclassicists would consider equivalent to price). Wrongs (1) and (2) played important, possibly dispositive, roles in the Workingmen's Amalgamated decision; yet neither can be translated into the

\footnotetext{
city's interstate and foreign commerce.").

144. Workingmen's Amalgamated Council, $54 \mathrm{~F}$. at 995, 999-1000.

145. Id. at 1000 .

146. Id. at 996.

147. See Loewe v. Lawlor, 208 U.S. 274, 310 (1908) (endorsing the extension of the Sherman Act).

148. Workingmen's Amalgamated Council, $54 \mathrm{~F}$. at 995.

149. Id. at 999 .
} 
contemporary framework, and Wrong (3) must be read in the context of both. Further, Wrong (3) itself is put forth not merely as a special instance of the general proposition, "sellers of commodities may not constrict supply in order to influence price," but rather as the specific proposition, "workers may not stop working in order to influence wages and working conditions."

In the opinion, Wrongs (1) and (2) are immediately evident in the court's initial statement of the issue. The court first described the decision made by workmen's organizations to "discontinue business" including "transporting goods which were being conveyed from state to state, and to and from foreign countries."150 When employers attempted to replace the union workers with non-union workers, they were met with "intimidation springing from vast throngs of the union men assembling in the streets, and in some instances by violence" (Wrong (1)). ${ }^{151}$ The result was that, by the intentional acts of the defendants, "not a bale of goods constituting the commerce of the country could be moved" (Wrong (2)). ${ }^{152}$ The question was, did these facts establish a cause under the statute? If the admittedly "lawful" organizations of workmen "adopt and further unlawful purposes and do unlawful acts ... the associations themselves become unlawful."153 So far, so clear. Everything then rode on what the "unlawful purposes" and "unlawful acts" were. The court answered that question as follows: "The evil, as well as the unlawfulness, of the act of the defendants, consists in this: that, until certain demands of theirs were complied with, they endeavored to prevent, and did prevent, everybody from moving the commerce of the country" (Wrong (3)). 154

The "certain demands," of course, consisted not in ransoms or some other inherently illegal purposes, but in moderately improved working conditions and wages, together with recognition of a collective bargaining representative (demands that, incidentally, would later become state-sanctioned purposes in the New Deal society). It is not academic to note this, because in the law of combinations from which the court was here borrowing, overtly nefarious and illegal aims were often the actual aims of the combinations at hand. In the identification

150. Id. at 1000

151. See id. (leaving aside the question of what shall count as coercion or intimidation in such circumstances, and granting arguendo that at least some actions that would legitimately qualify as unlawful harassment or coercion occurred).

152. Id.

153. Id.

154. Id. 
of the workers' "certain demands" with "evil," (i.e., Wrong (3)), we see the bridge to neoclassicism. In the "endeavoring to prevent everybody" we see the operation again of Wrong (1), which was probably necessary to justify the result in the classicist period. In the "from moving the commerce of the country," we see Wrong (2), the threat posed by workers' choice not to work.

\section{i. Violence and Coercion Toward Unwilling Third Parties}

Beginning with Wrong (1): was the "evil" the courts ascribed to the workers, "prevent[ing]" others from "moving the commerce of the country" or refusing to move the commerce of the country themselves? The former does a great deal of work in the opinion. Yet plainly, the defendants did not prevent "everybody" from doing so; plenty of individuals, including the defendants themselves, refused to do so quite voluntarily. The court had before it a voluminous evidentiary record resulting from the parties' vigorous contestation of precisely how significant or extensive the defendants' efforts were in preventing others from moving the commerce of the country. The court of appeal, in affirming the district court, noted that the latter had wide discretion to decide that factual contest as it apparently did, ${ }^{155}$ but the district court opinion itself contained no express finding of fact regarding the extent of any violence or coercion directed at willing and able workers. On the contrary, the court acknowledged the vast number of coordinated, voluntary individual decisions by workers that comprised the strike, describing the matter before it as a "gigantic and widespread combination"-implying voluntary decisions to agree-among the workers of New Orleans, spanning a "multitude of separate [workers"] organizations," all aimed at a work stoppage that would get the attention of those who profited from the "whole business of the city," who were also the ones who controlled the economic and material circumstances of the conspirators' lives. ${ }^{156}$ Indeed, it is fairly plain that if there had not been widespread agreement among a large number of workers to engage in the action - that is, if there had not been a critical mass of voluntary individual decisions involved in the coordinated action--the City, the employers, and the court would not have bothered with it in the first place. Not even the district court opinion ever really denied this.

155. Workingmen's Amalgamated Council of New Orleans v. United States, 57 F. 85 (5th Cir. 1893) (issuing a single-page, summary affirmance).

156. Workingmen's Amalgamated Council, 54 F. at 995. 
Yet, it seems that the court also predicated its antitrust analysis to a great extent on the proposition that intimidation "in some instances by violence" of others (employers or third-party workers) became a central means of the collective action, that is, Wrong (1). This idea pervades the opinion. Even after articulating Wrong (3) toward the end of its discussion, the district court chooses to end the opinion by again identifying the central evil at hand as the improper coercion of others, together with the halting of commerce-namely, a repetition of Wrongs (1) and (2), with no mention of the "certain demands," Wrong (3), that allegedly motivated both:

It is the successful effort of the combination of the defendants to intimidate and overawe others who were at work in conducting or carrying on the commerce of the country, in which the court finds their error and their violation of the statute. One of the intended results of their combined action was the forced stagnation of all the commerce which flowed through New Orleans. This intent and combined action are none the less unlawful . . . 157

This is striking not only in that this crucial proposition is never truly endorsed by the fact finder. It is remarkable also in that, in order to proscribe such conduct, or combinations of men employing such means, the court had no need to invoke the Sherman Act in the first place. Such combinations would already have been illegal under any interpretation of the common law at the time, and not just as a matter of economic regulation. It seems that the court went out of its way to apply the new statute.

\section{ii. Interrupting Commerce by Refusing to Work}

The conception of free trade as "the uninterrupted flow of trade" allowed the court to effectively require workers to work in order to prevent "a restraint of trade," that is, a violation of the Sherman Act. The court's concern with building and protecting the nascent national market is evident in its articulation of this requirement.

In its short decision, the court repeatedly stated that the workers stopped, and intended to stop, commerce by not working: "threatened that ... all the men ... would leave work"; "the whole business of the City of New Orleans was paralyzed"; "flow of commerce... [was] purposely arrested"; "transportation of the goods and merchandise from the government warehouses to the landings was forcibly stopped"; "enforced a discontinuance of labor in all kinds of business, including

157. Id. at 1000 (emphasis added). 
the business of transportation of goods and merchandise which were in transit through the city of New Orleans"; "not a bale of goods constituting the commerce of the country could be moved"; "forced stagnation of all the commerce which flowed through New Orleans"; "should the journeymen bakers refuse to work." 158 In most of these instances, the court mentions the interruption of work and commerce as a stand-alone fact, not conditioned upon a demand of improved wages or conditions-demonstrating that it saw it as an evil in itself (not as an evil only if used to influence price).

Indeed, the court at one point actually seemed to reason that "secur[ing] ... the employment of none but union men" is not in itself the wrong; this, of course, is the potentially monopolistic purpose that a contemporary court (putting aside for a moment the labor exemption) might condemn. Rather, it suggested that the wrong is the meanshalting work, and thereby commerce-by which that purpose was achieved, putting a primacy on the interruption of commerce by the refusal to work:

The defendants urge ... that the combination to secure or compel the employment of none but union men is not in the restraint of commerce. To determine whether the proposition urged as a defense can apply to this case, the case must first be stated... . The combination setting out to secure and compel the employment of none but union men in a given business, as a means to effect this compulsion, finally enforced a discontinuance of labor in all kinds of business, including the business of transportation of goods and merchandise which were in transit through the city of New Orleans, from state to state, and to and from foreign countries. When the case is thus stated... I do not think there can be any question but that the combination of the defendants was in restraint of commerce. ${ }^{159}$

The court very clearly stated that in order to determine whether the defendants' pursuit of "the employment of none but union men" in certain industries was legal, it had to consider the means defendants employed to secure this aim. Because those means consisted in "a discontinuance of labor in all kinds of business"-significant and voluminous business constituting interstate commerce-there could be no question but that the combination was in restraint of commerce. This is a precise inversion of neoclassical antitrust analysis, which would be concerned with the potentially monopolistic end. Instead, it evidences

158. Id. at 995-96, 999-1000.

159. Id. at 999 (emphasis added). 
the old obsession with workers who dare to not work, as one of the greatest social threats around. 160

In that older line of thinking, workers' status within commerce is as objects, not as agents, and any expression of their agency within that sphere is an affirmative threat. Expression of agency aimed at the purpose of not working, thereby threatening commerce, is the most threatening of all. This brings out the fundamental paradox of this notion of parity, which ascribes to workers the status of commercial agents (in the result) as well as objects (in the reasoning).

Once again, as with Wrong (1), the court relied upon the old common-law tradition regulating workers, in order to find a violation of the Sherman Act in their collective action to improve their working conditions. While Wrong (1) demonstrates the logical superfluity of the court's invocation of the new Act, Wrong (2) reveals how the court relied upon the hierarchical and coercive character of the common-law tradition with respect to workers, in doing so.

\section{iii. A Work Stoppage Aimed at Improvement of Working Conditions}

And what of the sole "evil" identified by the court that we may translate into a contemporary antitrust framework? As I have argued, it is not possible to interpret the court's holding as consisting only or even primarily in this, for the following reasons. First, the opinion is shot through with repeated invocations of Wrongs (1) and (2). As argued above in the discussion of Wrong (2), the court expressly stated that the evil was the means employed - that is, the cessation of work to interrupt commerce. ${ }^{161}$ And, on the heels of its single viable identification of Wrong (3) as an evil in itself, it again returned to its exaggerated focus upon the coercion of third parties-almost as if it felt it immediately had to buoy up insufficiently firm ground. Thus, I do not think there is a viable reading of the opinion in which the court primarily grounds the application of the Sherman Act to worker collective action upon Wrong (3).

However, assuming arguendo that Wrong (3) was one of the court's grounds of decision, the justification for it, too, was based upon ancient notions of hierarchy and control. That is because the court's condemnation of workers' conditional work stoppage was in terms that are highly specific to the workers' status as workers, rather than generally as sellers of commodities (of which labor, in the market

160. ORREN, supra note 98 , at 71-75.

161. Workingmen's Amalgamated Council, 54 F. at 999. 
society, happens to be one type). For its holding that this conduct is a violation of the Sherman Act, the court relied upon an old state court case applying the common law of labor combinations, whose elements are specific to the acts of workers, not sellers of commodities in general. The court spoke not of price-fixing, constriction of supply, or distortion of price. Instead, it had no sooner mentioned the workers" "certain demands" as comprising an aspect of the "evil" under the statute, than it was quoting a then-sixty-year-old New York criminal case that spoke and reasoned in terms of workers qua workers, and whose holding was limited to workers:

What is meant by "restraint of trade" is well defined by Chief Justice Savage .... "Should the journeymen bakers refuse to work unless for enormous wages, which the master bakers could not afford to pay, should they compel all journeymen in the city to stop work, the whole population must be without bread.... Such combinations would be productive of derangement and confusion, which certainly must be injurious to trade." 162

The quote and the case it was taken from are instructive regarding the court's perspective on worker collective action. ${ }^{163}$ People v. Fisher, upon which the Workingmen's Amalgamated district court relied in order to hold that the New Orleans strike was a restraint of trade and thus a violation of antitrust law, had applied the common law of criminal conspiracy to punish an 1833 "conspiracy to raise wages" by the journeymen shoemakers of Geneva, New York. 164 The New York case held that journeymen, who are paid wages by the masters, commit a crime by withholding labor on condition of higher wages-not that sellers commit a crime by combining to inflate prices in the product market. So in applying the argument from parity to extend a piece of commercial regulation to workers on the theory that they are sellers of commodities and thereby subject to that regulation, the court relied upon sixty-year-old precedent regarding workers' combinations, not regarding combinations of merchants. Moreover, every single point of authority, most of them English cases and statutes, collected in Fisher regard workers collectively withholding labor to affect wages or

162. Id. at 1000 (quoting People v. Fisher, 14 Wend. 9 (N.Y. 1835) (emphasis added)).

163. Note that it also again makes reference to the workers' "refus[al] to work," longconnected with the idea of social "derangement and confusion," in a manner that seems to go beyond the "enormous wages" themselves. Thus, in one of the few passages in the opinion that articulates Wrong (2)-the only one that could make the journey into contemporary antitrust analysis - the long shadow of Wrong (3) again appears. Fisher, 14 Wend. at 19.

164. Id. at 15 . 
working conditions. 165 The Fisher opinion also invoked statutes regulating workers' combinations dating to the "reign of Edw[ard] VI and Geo[rge] III, which subject workmen conspiring either to reduce the time of labor or to raise their wages, to the punishment of fine and imprisonment," that is, to the repressive, highly status-specific regulation of the eras $1547-1553$ and $1760-1820$, respectively. 166 Not one point of authority contained in Fisher regarded sellers of commodities collectively engaged in constricting supply in order to influence price; all concerned workers.

In other words, Fisher reasoned and spoke in terms of what it is appropriate for workers to do and not do, not in terms of what it is appropriate for sellers of commodities to do and not do. This seems to betray a view of workers that is somewhat in tension with the idea that they are simply an instance of the category "seller of a commodity"for otherwise, why not frame the principle in terms of the latter? The tradition of social control of working people embodied in the common law of employment, which is expressly continued in Fisher and invoked as authority in Workingmen's Amalgamated, in fact views workers as having a distinct status meriting specific, coercive legal treatment. 167 This may not be surprising in the context of Fisher, but should be surprising in the context of Workingmen's Amalgamated. After all, that was the decision that purported to extend to workers the free agency applied to men of commerce-to bring parity to how workers and businessmen were treated in the economic regulation of their collective action. 168

Fisher in fact represented the far end of the spectrum in terms of the American common law's repression of workers. William Forbath identified it as among a "famous handful of cases in the first quarter of the [nineteenth] century [that] seemingly held mere combinations to raise wages criminal... . These cases are the basis of the view that American labor law's trajectory over the nineteenth century was one from repression toward relative toleration." 169 The first court to apply

165. Id.

166. Id.

167. ORREN, supra note 98 , at $71-75$.

168. Not only is the court's reasoning entirely specific to workers qua workers, but it expressly reasons from outcomes-the reasonableness of the prices set for labor in the overall social order (a consideration that would not be allowed in the neoclassical framework, wherein the reasonableness or social utility of the prices set is no defense to anticompetitive conduct, as set out further in Part IV, infra).

169. FORBATH, supra note 20 , at 60 n.2. 
the Sherman Act to worker collective action aligned itself with the far end of the common law's spectrum of worker "repression," a feudal tradition of ancient vintage that viewed workers as lower in the social order than those for whom they worked, and thereby for many purposes not entitled to free agency over their actions.

The purpose for which the court invoked its age-old power to subordinate workers' economic and political freedom was that of avoiding "derangement and confusion" that would be "injurious to trade."170 In other words, it was the specific project of constructing a continuous national market and the emerging market society: ensuring that capital could earn a "reasonable" rate of return, ${ }^{171}$ enough to ensure continuing development, production, and investment. The judicial project of market construction thus paralleled the economic and physical project of building railroads, factories, and taming new natural resources, and it required abrogating workers' political and economic freedom to accomplish.

\section{b. The Danbury Hatters Case}

Loewe v. Lawlor, 172 better known as the Danbury Hatters case, grew out of one of the first union label boycotts, or coordinated "sympathy strikes," and in it, the Supreme Court "confirmed what a majority of lower federal courts"-Workingmen's Amalgamated and United States v. Debs ${ }^{173}$ - "had previously held: "that the Sherman Act applied to

170. United States v. Workingmen's Amalgamated Council of New Orleans, 54 F. 994, 1000 (E.D. La. 1893) (quoting Fisher, 14 Wend. at 19).

171. BENSEL, supra note 84 , at 289-354 ("The Political Construction of the National Market"). Consider the more obvious arm of this judicial market-building enterprise: the Lochner line of substantive due process cases, in which "any regulatory act that prevented a person or corporation from earning a reasonable return on invested capital was deemed a constitutional violation." Id. at 334. The same courts invoked the same language - "unobstructed" or "free," "flow" or "course," of "trade" or "commerce"-in both lines of cases to signify the same larger project.

172. 208 U.S. 274 (1908).

173. United States v. Debs, 64 F. 724, 729 (N.D. Ill. 1894). Debs arose out of the national Pullman strike, "the web of sympathetic boycotts of Pullman cars by the American Railroad Union in response to Pullman's ruthless wage cuts and his intransigent refusal to confer with his employees." FORBATH, supra note 20, at 74. To "virtually all of the nation's legal elite, conservative and reformist alike," the strike became a symbol of an anarchic threat posed by industrial unionism. Id. The federal judiciary responded with the usual sweeping injunctions, also many times calling in federal troops and presiding over mass arrests, although there was little violence or property damage before the crackdowns. Judge William $\mathrm{H}$. Taft wrote in contemporaneous letters to his wife: "Until they have had much bloodletting, it will not be better" and "They have killed only six of the mob as yet. This is hardly enough to make an impression." Id. Debs and other union officers were prosecuted under, inter alia, the Sherman Act; the Supreme Court denied their writ of habeas corpus on alternate grounds, namely Congress's 
combinations of workers." 174 As painfully chronicled by William Forbath in his seminal work on the Gilded Age judiciary's effect upon the labor movement, the saga was devastating to the morale of that movement, sucking many of its resources in those key years and robbing it of some of its most successful tactics. ${ }^{175}$

Significant as it was in its impact, Danbury Hatters delved no deeper into the justification for bringing worker collective action under the Sherman Act than had Workingmen's Amalgamated. 176 In fact, the Supreme Court largely relied on the reasoning of the Louisiana federal district court on this point, quoting it at length for the proposition that workers were not to be exempted from the Sherman Act.177 Other than that lengthy excerpt, the only other reasoning the Court offered for its application of the Sherman Act to worker collective action was this assertion: "The records of Congress show that several efforts were made to exempt, by legislation, organizations of farmers and laborers from the operation of the act, and that all these efforts failed, so that the act remained as we have it before us." 178 As an inference about legislative intent, this is likely incorrect. ${ }^{179}$ It is also incorrect that any such amendments "failed": the only one that was proposed in fact passed, and no amendment was proposed to the rewritten bill (and thus could not have failed). ${ }^{180}$ As an assertion that there did not at that time exist an express labor exemption, it is of course true, but that alone does not answer the question whether the Act ought to regulate worker collective action.

The Court also quoted Workingmen's Amalgamated's statement of its central holding (in addition to its statement that the Sherman Act applies to workers), apparently adopting its reasoning for why worker collective action was a restraint of trade under the Sherman Act, ${ }^{181}$ and thereby perpetuating its reliance upon the common law's repression of free action by workers qua workers.

authority over interstate commerce, particularly as exercised in various statutes specific to railroads and the carriage of the mails.

174. FORBATH, supra note 20 , at 92.

175. Id. at 92-94.

176. The Court did not rely on any of the reasoning of the district court in Debs, simply noting that its affirmance on alternate grounds was not meant to disapprove the lower court's application of the Sherman Act. Loewe, 208 U.S. at 298-99.

177. Id. at $301-02$.

178. Id. at 309-10.

179. See supra Part II.B.

180. Id.

181. Loewe, 208 U.S. at 302. 
Even more directly, although it refrains from itself articulating its principles in terms that rely upon workers' status qua workers, the Danbury Hatters opinion included the following reliance on authority:

The combination charged falls within the class of restraints of trade aimed at compelling third parties and strangers involuntarily not to engage in the course of trade except on conditions that combination imposes; and there is no doubt that (to quote from the well known work of Chief Justice Erle on Trade Unions) "at common law every person has individually, and the public also has collectively, a right to require that the course of trade should be kept free from unreasonable obstruction." 182

This ("the course of trade should be kept free from unreasonable obstruction") ${ }^{183}$ is the same concept of free trade employed in Workingmen's Amalgamated. Such obstruction includes not only affirmative acts of interference, but also, it turns out, the omissions of not working, if those omissions are entered into collectively and deliberately. The free flow of national trade had to be protected because building the national market was a priority for the Court.

Again, the project of building the emerging market society met (and relied upon) the status-specific tradition of restrictions upon workers' freedom of action. There was no further elaboration, footnote, or explanation in the opinion regarding the "well known" source mentioned, which was a treatise relating to workers and their organizations, not to sellers of commodities or trade combinations generally. Sir William Erle was at one time Chief Justice of the Court of Common Pleas, and a member of the Commission on Trade Unions created by Parliament to make recommendations to it, and who later authored The Law Relating to Trade Unions. ${ }^{184}$ Erle seemed to endorse then-current English common-law ideas about what it was proper for workingmen to do vis-à-vis the free flow of trade. For example, deciding whether a group of workers could be convicted under the 1823 Master and Servant Act for willfully absenting themselves from their work in a shipyard, he had in another case written:

[The statute] was meant to protect persons who had heavy contracts to complete within a certain time, and to give them a summary remedy in case their workmen left them without a reasonable excuse. Under some circumstances a person employed to do a particular job would

182. Id. at 294-96 (emphasis added).

183. Id.

184. William Erle, The Law Relating to Trade Unions (1869). 
not be the servant of his employer, but not when the employment is such as in this case. ${ }^{185}$

In other words, that statute was meant to protect commerce from workmen (not working). This is the very theme that pervades the Workingmen's Amalgamated opinion. The "free flow of commerce" argument thus justifies curtailing workers' political and economic freedom to organize for betterment of their conditions.

\section{The Corporate Exemption}

The key move in the foregoing cases - relying upon the ambiguity in the concept "free trade" in order to curtail workers' freedoms for the purpose of constructing the emerging market society-is brought into especial relief when we consider the same courts' and thinkers' attitude toward business corporations. In the Gilded Age, labor collective action was prosecuted far more than businesses' under the Sherman Act. ${ }^{186}$ Beyond this, businesses had little need to engage in overt price-fixing, for a combination of the "corporate exemption" and the relative lack of regulation of mergers allowed them to simply collect market power within individual firms.

Classicism actively promoted that central device of business combination, the corporation, as a site of economic and ultimately political power. As previously mentioned, early corporations were quasi-public creatures that operated under a web of constraints for specific state-sanctioned purposes, not legal forms used to collect capital while limiting liability. 187 These constraints were gradually lifted over the course of the nineteenth century, via various changes in the law of corporations that increasingly insulated owners and shareholders from liability while enabling the separation of ownership

185. Lawrence v. Todd (1863) 143 Eng. Rep. 562, 14 C.B. (N.S.) 554; RoBERT J. STEINFELD, COERCION, CONTRACT, AND FREE LABOR IN THE 19TH CENTURY 145, 151 (2001). In another case, the Chief Justice wrote, in deciding whether a wage statute applied: "We should look at the work done and the position in life of the parties." Id. at 145.

186. EDWARD BERMAN, LABOR AND THE SHERMAN ACT 271 (1930) (explaining that the first twenty cases prosecuted under the Act targeted worker collective action to improve working conditions); BENSEL, supra note 84 , at 342-43.

187. HOVENKAMP, supra note 85, at 13-14 (noting that the distinguishing elements of the preclassical corporation were "not its structure or its ability to assemble capital" but rather its "special contract (charter) with the state, permitting the incorporators to do something that no one else could do"); TOMLINS, supra note 85 , at 24 (describing the "decline of the corporation as a public body and the appearance, by the end of the second decade of the nineteenth century, of a new archetype: 'the modern business corporation, organized to pursue private ends for individual gain"). 
and control. ${ }^{188}$ During the Gilded Age, the innovation of additional legal doctrines beyond the law of corporations allowed these new creatures to fully spread their wings: into the industrial production process, into surrounding markets, and into a powerful and enduring role in the polity. ${ }^{189}$

Regarding corporations' legal status as combinations, the justification seemed to draw in part from their prior status as creatures operating in the public interest, ${ }^{190}$ eventually evolving into efficiency justifications based on economies of scale and on emerging concepts of scientific management and production. ${ }^{191}$ The selective approval of classicists (and their immediate predecessors) for the "co-operation" embodied in business combinations, composed of men of their own class, in contrast to their ambivalence or hostility toward the co-operation of men and women who contributed their physical labor to society, was widely noted at the time. ${ }^{192}$ Herbert Hovenkamp has surveyed the comparative treatment of business and labor combinations by Gilded Age theorists and courts, concluding that labor combinations got the short end of the stick for structural reasons rather than due to overt bias. ${ }^{193}$ While a fuller exploration will have to be saved for future work, there are considerations that suggest that bias and structure in fact worked together to create this result. Adam Smith (who may be presumed an at least neutral observer) commented upon the selective disapprobation far earlier. ${ }^{194}$ That vintage is an indication of the ancient social attitudes

188. HOVENKAMP, supra note 85 , at 14-16.

189. TOMLINS, supra note 85, at 16-20 (explaining the consolidation of corporate control over industrial production, previously controlled independently by workers or craft organizations); see id. at 25-30 (detailing the triumph of corporate decision making over state and local regulation of local markets).

190. TOMLINS, supra note 85 , at 23 .

191. See, e.g., Hovenkamp, supra note 112 , at $938-40$ (discussing contemporaneous commentators' arguments that business combinations result in increased efficiencies, lower overall prices, and better product quality).

192. See, e.g., Francis B. Sayre, Criminal Conspiracy, 35 HARv. L. REV. 393, 420 (1922) ("[W]hy should the law be such that if two steel workers plan a certain act which the law regards as tortious, they should be subject to fine and imprisonment; but if, let us say, the United States Steel Corporation plans and executes the self-same action, the criminal law should be unable to touch it?').

193. Hovenkamp, supra note 112, at 965 ("Labor combinations received the same treatment. But the unique structure of the labor market-easy entry and no economies of scale-meant that the new law had far harsher impact on labor combinations than seller cartels.").

194. He stated:

We rarely hear, it has been said, of the combinations of masters, though frequently of those of workmen. But whoever imagines, upon this account, that masters rarely combine, is as ignorant of the world as of the subject. Masters are always and 
that contributed to this view. Classicists also seemed to view enhanced business profits as a social good in a way that they did not regard wage premiums. That, of course, is an unprincipled distinction even before introducing normative commitments to workers' welfare. ${ }^{195}$ It can even be glimpsed in classicists' sweeping statements that business "cooperation" was necessary for social progress. For example, the same Arthur Eddy who had urged the extension of the Sherman Act to labor organizing had this to say:

Social progress would be impossible were if not for co-operation and combination; therefore the law encourages and recognizes the formation of-

1. Partnerships

2. Voluntary associations

3. Corporations

All of which are combinations in every sense of the term-a corporation being simply the co-operation of two or more individuals in a form of combination prescribed by law. 196

Yet, in what Hovenkamp calls Eddy's "trite apology" for business combinations, the latter asserted that business combinations "are all in the direction of more for less money," while "labor unions and farmers" organizations are all in the direction of less for more money." It is difficult to read Eddy's use of "more" and "less" here as a nonperspectival view from nowhere. More, his inclusion of farmers' organizations on the side of labor rather than business also suggests a clear identification with a specific economic (and political) class and associated interests, rather than some neutral distinction (assuming

everywhere in a sort of tacit, but constant and uniform, combination, not to raise the wages of labour above their actual rate. To violate this combination is everywhere a most unpopular action, and a sort of reproach to a master among his neighbours and equals. We seldom, indeed, hear of this combination, because it is the usual, and, one may say, the natural state of things, which nobody ever hears of. Masters, too, sometimes enter into particular combinations to sink the wages of labour even below this rate. These are always conducted with the utmost silence and secrecy till the moment of execution.

ADAM SMITH, WEALTH OF NATIONS 60 (1776).

195. See Hovenkamp, supra note 112, at 940 ("When mainstream American political economists around 1900 viewed business combinations, they saw increased efficiencies from economies of scale, lower overall prices, better product quality, and higher profits."). Note that the inclusion of "profits" in this category is rank hypocrisy even on this outlook's own principles, because its analogue, higher wages, would never be seen as an independent good and in fact would be viewed as an inefficiency. On neoclassical economic theory, too, profits (beyond what is needed to compensate the opportunity cost of capital) are by definition inefficient.

196. EDDY, supra note 134 , at 1327. 
arguendo that there is such a principle that would justify harsher treatment for labor) between sellers of labor and sellers of other commodities.

At any rate, as with prosecuting worker collective action under the Sherman Act, the courts endorsed the classicist outlook on business combinations in their construction of the Act. In United States v. JointTraffic Ass' $n$, "the Court ... directly addressed" the anxiety, raised in an earlier dissent, that the Court's broadening of the common-law rule on price-fixing might "carry the implication that . . . business organizations . . . violated the Sherman Act" in themselves. 197 We might call the Court's removal of this doubt the corporate exemption, to parallel the labor exemption that the courts rejected.

This combination of the corporate exemption with the relative toleration for mergers meant that business had less need to engage in overt price-fixing. While "the government was generally more successful in prosecuting labor unions than industrial combinations [under the Sherman Act]," "[w]ith respect to industry, [the Act] became moribund... even as corporate mergers and combinations swept the American economy."198 Together with the corporate exemption, this meant that large industrial actors' consolidation of market power was largely unregulated: collective action that took place within a business firm was entirely immune, while the relatively permissive attitude toward mergers allowed firms to attain market shares that gave them market power, often of monopolistic magnitudes. Meanwhile, workers' attempts to act collectively in order to improve the terms of their labor for these firms were prohibited and punished by the Act.

The bottom line is that corporations, once legally formed, were simply not treated as combinations anymore at all, but as single units. Not so for workers' combinations, and certainly not so for ad hoc workers' combinations that came together for particular instances of collective action. Indeed, even assuming that a particular workers' organization were considered legal, once it struck, the law viewed the acts as those of individuals in a combination, rather than a single unit (in contrast to the acts of the employer, a business organization). 199

197. HYLTON, supra note 13, at 94; see United States v. Joint-Traffic Ass'n, 171 U.S. 505, 567 (1898) ("[T]he formation of corporations for business or manufacturing purposes has never, to our knowledge... been regarded in the nature of a contract in restraint of trade or commerce.").

198. BENSEL, supra note 84 , at $342-43$.

199. Still, at least the classicists spoke expressly of the corporation as a combination. In the modern understanding, the concept is so entrenched that the fundamental unit in antitrust analysis 


\section{The LABOR EXEMPTION: AN UNSTABLE PARADIGM}

The doctrine that the Gilded Age courts had created, applying the Sherman Act to limit and punish worker collective action, went largely underground during the New Deal era. There it was fertilized by the emerging neoclassical consensus in antitrust, and was undisturbed by a deferential labor exemption that built around it instead of uprooting it.

The labor exemption case law was a part of the New Deal paradigm of economic regulation, and also an especially charged symbol of it. Within the New Deal paradigm, the market society that had been constructed during the Gilded Age in large part through cooperation between courts and industry, now expanded to include a place for collective bargaining by workers. Unions left the legal shadows, becoming market actors alongside business firms. This new paradigm, on the one hand, embraced a vision where economic life was governed in tripartite fashion by the state, capital, and organized labor. At the same time, it rarely articulated that vision, much less a set of underlying principles in support of it. This was in contrast to the market framework that it partially displaced, and with which it partially coexisted. The theory behind antitrust policy, by contrast, was increasingly seen as near-scientific and as transcending normative contestation. Together, these factors resulted in a period of "normal science" of the labor exemption. 200

The law of the labor exemption thus largely ceded ideological primacy to the market framework, even as the results it prescribed staked out a temporary bulwark against that framework's most extreme and violent manifestations: carving out a place for limited economic democracy for a limited number of working people for a limited period of time. At the same time, it perpetuated the idea of "two rival policies"

is "the firm" (whether a corporation, partnership, or individual). The labor exemption when it appeared at the dawn of the New Deal period only partially equalized this state of affairs, because the parallel system for regulating labor combinations was quite onerous, and continued to essentially impose a tradeoff upon organized labor for allowing the combination in the first place, thus continuing to view it as a combination. In other words, while business corporations may not combine to engage in concerted action targeting a competitor or to raise prices, a business corporation on its own is viewed as a single actor, and thus there are no restrictions on its conduct paralleling the restrictions contained in the NLRA. See generally TOMLINS, supra note 85 .

200. I use here the notion of "normal science"-coined in THOMAS KUHN, THE STRUCTURE OF SCIENTIFIC REVOLUTIONS 5 (1962), and subsequently applied in descriptions of a huge variety of fields (science and otherwise) - to describe the period after a "paradigm shift," when the focus is on implementing and clarifying the new paradigm rather than on basic or first principles. 
that were fundamentally opposed. This opposition went hand in hand with an acceptance of the basic premise that the policy of antitrust would in fact prescribe a different result for worker collective action than the law of the labor exemption did. The law of the labor exemption both expressly and implicitly endorsed this premise.

\section{A. The Norris-La Guardia Act}

The text, structure, and operation of the labor exemption reinforced both the primacy of antitrust and the supposed separateness of the principles and values upon which labor and trade regulation, respectively, rely. The Norris-La Guardia Act, ${ }^{201}$ one of the first pieces of New Deal legislation, although it partially revived and then operated together with the labor provisions of the earlier Clayton Act, came to define the ethos of the labor exemption. The text of the Norris-La Guardia Act does not engage directly with the framework it is modifying, hardly articulates its own principles, and seems to be the product of a conscious decision to so demur.

Unlike the Clayton Act, which was the first legislative attempt at a labor exemption from antitrust, 202 the Norris-La Guardia Act did not grapple directly with trade regulation in subject matter-even with how trade regulation applies to labor-although it had the effect of modifying its reach. Norris-La Guardia is not an antitrust statute. Instead, it is incorporated into Title 29 ("Labor") of the United States Code. By contrast, the Clayton Act was conceived and written as an antitrust statute, was incorporated into Title 15, the antitrust and trade regulation section of the Code, and portions of it dealt with matters other than labor.

201. Act of Mar. 23, 1932, ch. 90, 47 Stat. 70 (codified as amended at 29 U.S.C. $\S \S 101-115$ (2012)).

202. Act of Oct. 15,1914 , ch. $323, \S 1,38$ Stat. 730,730 (codified as amended at 15 U.S.C. $\S$ 12 (2012)). Section 20 of the Clayton Act had limited the availability of injunctions in disputes relating to the terms and conditions of employment. Id. $\S 2,38$ Stat. at 738 (codified as amended at U.S.C. § 52). Those provisions were nearly laid flat by the pre-Roosevelt Supreme Court in Duplex Printing Co. v. Deering, which held that the union's objective (a closed shop) and method (secondary boycott) were illegitimate, and thus fell outside the statute (thus also creating an opening for courts to import additional extra-statutory understandings of legitimate objectives and methods back on the part of working people). 254 U.S. 443, 477-78 (1921). United States v. Hutcheson (discussed for other purposes, infra) revived section 20 by reading the Clayton Act in conjunction with Norris-La Guardia, holding that together they protected the enumerated activities from both injunctions and actions for damages. 312 U.S. 210, 211 (1940). Interestingly, Duplex Printing on its face did not hold that a strike for higher wages would be an illegitimate activity and thus would not be protected by the labor exemption. This reflects the fact that the courts of this period were still not consistently applying neoclassicist analysis, under which such an action would be classic price-fixing-assuming antitrust applies to labor. 
In content, Norris-La Guardia also does not deal directly with the subject matter, provisions, or logic of trade regulation. Its text does not include any reference to antitrust or to the Sherman Act, nor to the subject matter of its provisions. ${ }^{203}$ Norris-La Guardia's central edict is the following:

No court of the United States, as defined in this chapter, as defined in this chapter, shall have jurisdiction to issue any restraining order or temporary or permanent injunction in a case involving or growing out of a labor dispute, except in a strict conformity with the provisions of this chapter; nor shall any such restraining order or temporary or permanent injunction be issued contrary to the public policy declared in this chapter. ${ }^{204}$

The statute then goes on to enumerate acts, involving or growing out of a labor dispute, that a court may not enjoin,205 and to set out the conditions that shall define "involving or growing out of a labor dispute."206 Nowhere does it refer to restraints of trade or to monopolies-the central subjects of the Sherman Act-or attempt to redefine them as they relate to labor. ${ }^{207}$ Again, by contrast, the Clayton Act famously asserted: "[T]he labor of a human being is not a commodity or an article of commerce." 208 That proposition directly and

203. The only section in which it even approaches the subject matter of antitrust is when it states, derivatively of its central provisions:

No court of the United States shall have jurisdiction to issue a restraining order or temporary or permanent injunction upon the ground that any of the persons participating or interested in a labor dispute constitute or are engaged in an unlawful combination or conspiracy because of the doing in concert of the acts enumerated in section 104 of this title.

Act of Mar. 23, 1932, ch. 90, § 5, 47 Stat. at 71 (current version at 29 U.S.C. $\S 105$ ) (emphasis added). Even this speaks more to common-law conspiracy than antitrust, for the latter is specific about its subject matter-restraint of trade-unlike the common law, which could relate to any illegal act or predicate.

204. Id. $\S 1,47$ Stat. at 70 (codified as amended at 29 U.S.C. $\S 101$ ).

205. Id. $\S 4,47$ Stat. at 70 (codified as amended at 29 U.S.C. $\S 104$ ).

206. Id. $\S 13,47$ Stat. at 73 (codified as amended at 29 U.S.C. $\$ 113$ (a), (b), and (c)).

207. This is not entirely surprising, in that Norris-La Guardia was aimed not just at antitrust, but more generally at what was then often called the "government by injunction" legislated by Gilded Age courts in the domain of labor. In this, the courts had used antitrust, to be sure, but also the old common-law concepts of conspiracy and property interests of the employer, to justify blanket injunctions against worker collective action. Yet, as to either theory of liability, the Act was equally pragmatic and results-focused in approach. There is simply less reason to comment on its failure to grapple with the property-based common-law bases for liability because those, unlike the Sherman Act, are no longer used (although, as I argued in Part II, supra, their vestiges may live in the Sherman Act, and others have argued that their vestiges live in statutory labor regulation as well).

208. Act of Oct. 15,1914 , ch. $323, \S 6,38$ Stat. 730,731 (codified as amended at 15 U.S.C. 
forthrightly challenged antitrust law's application to labor, for if labor is not a commodity, then it is nonsensical to speak of restraining trade in it or of fixing prices in it. The Norris-La Guardia Act offered no analogous rationale for its limitations of the effect of antitrust regulation upon labor.

William Forbath described the momentum that fueled the Norris-La Guardia Act in two stages: the first, dominated by the more oldfashioned "rights talk" of the trade unionists, and the second, which resulted in the bill that was actually passed, dominated by the ascendant Progressive architects of the New Deal, notably Felix Frankfurter. ${ }^{209}$ Forbath's emphasis is on the degree to which these two approaches were laissez-faire or statist: distrustful of the government's involvement in labor matters (the first, union-dominated phase) or optimistic about its possibilities (the second, Frankfurter-dominated phase). Another difference, implicit in his account, is the extent to which the two approaches met the theory of liability that they challenged head on, in a clash of principles (the first phase), or opted for a more pragmatic, results-oriented approach (the second phase). ${ }^{210}$ The approach that won out was the pragmatic, results-oriented statutory text just discussed. Saving the statute from constitutional scrutiny may have been the most pragmatic course at the time, ${ }^{211}$ but the manner of doing so also set the tone for the "normal science" period of the statute to follow. Although Norris-La Guardia revived Clayton's labor provision, it imposed the

$\S 17$ (2012)). It also stated:

The labor of a human being is not a commodity or article of commerce. Nothing contained in the antitrust laws shall be construed to forbid the existence and operation of labor, agricultural, or horticultural organizations, instituted for the purposes of mutual help, and not having capital stock or conducted for profit, or to forbid or restrain individual members of such organizations from lawfully carrying out the legitimate objects thereof; nor shall such organizations, or the members thereof, be held or construed to be illegal combinations or conspiracies in restraint of trade, under the antitrust laws.

Id.

209. More generally, the second version of the legislation was associated with "the men and women who after 1932 became 'New Deal attorneys' and the builders of a 'new American stats," a community of which Frankfurter was emblematic and, in a basic sense, helped to create. FORBATH, supra note 20 , at 165.

210. Forbath notes that "the vocabulary of Marx's Capital finds a strange echo in the words of 'pure and simple trade unionist' [Andrew] Furuseth," as he testified before Congress: "Now, if you are going to permit this kind of expansion of the word 'property' to cover every human relation, you set up a condition, gentlemen, under which the creator, the human being who through his creative power ... has created certain property, you make that man fall down on his knees and worship what he himself has produced." Id. at 161 (internal citations omitted).

211. Id. at 164 . 
cost of replacing its "rights talk" with its own pragmatic ethos. We see this in the labor exemption case law, which displays a general orientation toward effects over principle, and which in turn enabled the implicit primacy of antitrust policy over labor policy.

\section{B. Solidification of the Paradigm}

The transitional and foundational cases that came to define the normal science period showed no signs of reviving the rights talk of an earlier wave of challenges to the operation of the market society. Instead, these pivotal, paradigm-solidifying cases largely endorsed the primacy of antitrust, and reinforced the premise that absent a labor exemption, antitrust would regulate and often bar worker collective action.

\section{Apex Hosiery}

Apex Hosiery Co. v. Leader, ${ }^{212}$ decided by a very different Supreme Court than the one that had decided the key pre-New Deal precedents, came close to being something other than what it was. It is the sole decision that approached the proposition that the Sherman Act, on its own terms, does not apply to a large swath of worker collective action, and that is not an entirely unreasonable reading of the opinion. ${ }^{213}$ Yet a closer reading shows that the opinion actually affirmed the default applicability of antitrust law to worker collective action, failing some specific exception, and in so doing ratified its primacy. Moreover, the reasoning for carving out the exception again relied upon the affirmative New Deal labor legislation that had just passed and incorporated its limits.

The Court began by expressly rejecting the proposition that the Sherman Act does not apply to the concerted actions of workers to improve their wages and working conditions. Particularly notable are the grounds it gave for doing so: "On the contrary Congress has repeatedly enacted laws restricting or purporting to curtail the application of the Act to labor organizations and their activities, thus recognizing that to some extent not defined they remain subject to it."214

212. 310 U.S. 469 (1940).

213. See Susan Schwochau, The Labor Exemptions to Antitrust Law: An Overview, 21 J. LAB. RES. 535, 542 (2000) (stating Apex Hosiery "rested not on any statutory labor exemption, but on construction of the Sherman Act itself').

214. Apex Hosiery, 310 U.S. at 488. 
Here the Court expressly stated the point I have been urging regarding the development of the labor exemption and the default assumptions that it embedded in the law regarding the intersection of trade regulation and labor regulation: that the judicial construction of the Sherman Act in the classicist period, as applying to worker collective action, was actually preserved as the underlying rule even in the New Deal period, although its effects were greatly curtailed.

Having held that the activities of combinations of workers to better their terms of work are by default "subject to" antitrust regulation and prosecution, the Court then went on to hold that the particular acts in front of it were not antitrust violations. Specifically, the Court held that taking labor costs out of price competition was not a violation of the Sherman Act:

[S]uccessful union activity, as for example consummation of a wage agreement with employers, may have some influence on price competition by eliminating that part of such competition which is based on differences in labor standards. Since, in order to render a labor combination effective it must eliminate the competition from non-union made goods ... an elimination of price competition based on differences in labor standards is the objective of any national labor organization. But this effect on competition has not been considered to be the kind of curtailment of price competition prohibited by the Sherman Act. ${ }^{215}$

The opinion then immediately cited the recent New Deal labor legislation, offered in support of the proposition that legislative intent behind the Sherman Act was not to proscribe worker collective action. 216 The Court thus relied upon the affirmative labor legislation recently passed for its conclusion that the effect of worker collective action on price competition-perhaps the core issue-does not render that concerted action barred by antitrust. Sound reasoning or not, this rendered the Court's holding apparently dependent upon that new labor policy, particularly given that it already stated that worker collective action is by default subject to antitrust. Relatedly, and underscoring the same point, instead of overruling or disapproving of Loewe v. Lawlor, or any of the other classicist antitrust cases punishing worker collective action, Apex Hosiery distinguished them, another tacit endorsement of their basic logic. It distinguished them on the basis that the case before

215. Id. at 503-04.

216. Id. at 504 n.24 (citing Norris-La Guardia, but also the Wagner Act and the Fair Labor Standards Act). 
it did not involve secondary action, which had been prohibited because of the nature of the means rather than the nature of its effects, ${ }^{217}$ not because their effects on price competition were economically distinguishable.

All this has two immediate implications. First, it cedes significant ground to the emerging neoclassical antitrust framework by tacitly suggesting that there is no other reason why it ought not to apply-that but for a separately articulated statutory labor policy, there is indeed and ought to be a market for labor in all pertinent respects analogous to the market for products, justifying the same antitrust treatment for concerted action. The Court did not offer a meaningful principled alternative to the neoclassical economic perspective that was coming to define antitrust.

Second, the construction of the relationship between antitrust and one of the key objects of worker collective action was thus expressly limited by the New Deal labor framework's thresholds of applicability: legally, employee status; and many times practically, the existence of a labor organization formed according to a complicated bureaucratic structure that would only become more complex and restrictive as the century wore on. Those limitations are highlighted in today's deregulation economy, in which those thresholds are increasingly absent. Thus, even if the Court's holding can be understood to construct the Sherman Act alone, its statement of that holding plainly limits that construction to limits placed by New Deal labor legislation. Workers who fall outside the category "employee" are the most obvious evidence of the limits that have inhered in the law the entire time, but they may be figurative canaries in the coal mine.

The greatest immediate legacy of Apex Hosiery, meanwhile, was its elevation of the distinction between labor markets and product markets (and whether a restraint in the labor market has a "substantial effect" in the product market), in the law of the labor exemption. 218 This suggests a caveat to the reading I have offered, for the distinction between labor markets and product markets and its mention of the Clayton Act together may be read as a suggestion that the Court did, to some extent, endorse a basic distinction between the selling of labor and the selling of commodities. Yet in light of the entire opinion, in particular its

217. Id. at 505-06.

218. This left future courts to determine how close the connection to the product market must be, for the act by the labor union to be within the ambit of the Sherman Act. Schwochau, supra note 213 , at 543 . 
reliance on affirmative labor legislation and its failure to articulate any principle for the distinction, this is best read as a minor strain.

\section{Hutcheson}

That minor strain dissolved into a road not taken with United States v. Hutcheson. 219 Even more directly than Apex Hosiery, the Hutcheson decision relied upon the Norris-La Guardia and Clayton Acts, regarding those together with the Sherman Act as a set of "interlacing statutes." 220 Hutcheson read the Clayton Act's proclamation that that certain activities by combinations of workers "shall not be considered or held to be violations of any law" in combination with Norris-La Guardia's list of enumerated activities protected from injunction, essentially expanding that shield to immunize against not only requests for injunctive relief but actions for damages as well. Hutcheson's holding was broad and was a boon to the labor movement. But despite its partial resuscitation of the Clayton Act, it ignored the minor strain in Apex Hosiery, and relied expressly on the statutorily defined labor exemption. Instead of focusing on the distinction between the labor market and the product market, it "focused on the activities of labor organizations (due to the language of Clayton) and whether those activities fell within the class of activities exempted by Norris-La Guardia."221 Because "future cases employed the Hutcheson line almost exclusively," 222 this removed any vestige of the concept that labor is not and ought not be treated as a commodity from the main thrust of the labor exemption case law, and redoubled focus upon construction of a list of exempted activities, for which no real principle had been offered in the statute nor in the decision.

One reason Hutcheson had such immediate practical significance is that it removed the uncertainty left in the wake of Apex Hosiery regarding secondary actions by workers-"solidarity actions" (without which organized labor likely would not have amassed the political power necessary to pass New Deal labor legislation in the first place). ${ }^{223}$ This also may supply the explanation for why Hutcheson

219. 312 U.S. $219(1941)$.

220. Id. at 232 .

221. Schwochau, supra note 213, at 544; Hutcheson, 312 U.S. at 234 (reading the Clayton and Norris-La Guardia Acts together, to hold that the "bounds of a labor dispute" included, and therefore exempted, secondary action).

222. Schwochau, supra note 213, at 544 (citing PHILIP AREEDA \& HERBERT HOVENKAMP, ANTITRUST LAW: AN ANALYSIS OF ANTITRUST PRINCIPLES AND THEIR APPLICATION (1997)).

223. Despite the draconian character of the official pre-New Deal precedent regarding antitrust and worker collective action, much worker collective action including secondary action 
sidestepped the minor strain in Apex Hosiery and redoubled the focus on the affirmative statutory basis for an exemption. For Apex Hosiery had affirmed the general principle that the Sherman Act applied to worker collective action, relying largely upon the old cases, and then distinguished those cases on the basis that they involved secondary action. Thus, Hutcheson had to find some other basis for freeing secondary action from antitrust liability, and without overruling Apex Hosiery's construction of the Sherman Act, it did so by holding that regardless of what the Sherman Act meant, the statutory labor exemption immunized secondary action.

\section{The Normal Science of the Labor Exemption}

The normal science of the labor exemption framework solidified the suggestions in the foundational case law, largely adopting the relatively contingent threshold conditions of affirmative labor regulation rather than relying upon a principled distinction between labor markets and product markets (or some other principle), to define its boundary with antitrust. This fed grumblings about the special treatment accorded labor. It also led naturally to the result that independent contractor workers were subjected to antitrust liability, even while courts seemed to acknowledge their underlying status as workers.

\section{Generally}

Because Hutcheson, not Apex Hosiery, was largely the basis for the normal science of the labor exemption, the exemption was largely defined by the list of exempted activities set out in Norris-La Guardia. The main body of labor exemption case law tended to ignore the minor strain in Apex Hosiery, which may have been suggestive of a principled distinction between labor markets and product markets on the Sherman Act's own terms. The normal science of the labor exemption was instead mostly concerned with policing the boundaries of the exempted activities, and of the category of traditional activities of labor unions.

The normal science of the labor exemption was also defined to a great extent by its context, namely a basic economic policy of cogovernance by capital, the state, and labor. The trucking industry was an excellent example of this, with the Interstate Commerce Commission ("ICC") effectively setting rates in cooperation with industry and with

did as a matter of fact take place, sometimes escaping the iron fist of the judiciary and sometimes provoking overt repression; this did in fact contribute to labor's power, both economic and political. FORBATH, supra note 20, at 141-47. 
the Teamsters, the labor organization that represented a critical mass of truck drivers in the mid-twentieth-century period. 224

At the same time, the contemporaneous scholarly and policy commentary focused to a great degree upon the labor exemption as a symbol of a basic contest about economic worldviews that the New Deal era had not resolved, consisting as it did of a marriage between the official ideology of the market society with the actual practice of economic life. 225 In a mid-century article that provides a window into this commentary, antitrust scholar Ralph Winter noted the "irrational" primacy of the labor exemption in the contemporaneous "debates over labor policy," describing it (and the potential application of the Sherman Act to labor) as an "emotional symbol" of the clash of policies and perhaps worldviews. ${ }^{226}$ This description furnishes a clear contrast with the present day, where the labor exemption has been largely consigned to an arcane specialty practiced by a tiny subset of lawyers and receives little attention from scholars and almost none in the broader policy discourse. This is partly because the juice that was fueling that emotional symbolism was the challenge, however attenuated, that New Deal practice posed to official market ideology.

If the labor exemption itself had irrational primacy in policy debates in the mid-century period, 227 then the supposed conflict between antitrust policy and labor policy was almost always a presupposition of those debates. ${ }^{228}$ That presupposition was harmonious with the position of industry, which was that the conflict was acute and that labor's exemption from it was absolute and unprincipled, resulting in deleterious economic effects of significant magnitude. 229

\footnotetext{
224. BELZER, supra note 33 , at 55 .

225. Id.

226. Winter, supra note 15 , at 16.

227. The U.S. 1961-62 Intercollegiate Debate had as its topic: "Resolved: That Labor Organizations Should Be Under the Jurisdiction of Antitrust Legislation." LABOR \& ANTI-TRUST LEGISLATION 1 (Harold S. Roberts ed., 1961); see also Comment, The Antitrust Laws and Labor, 30 FORDHAM L. REV. 759, 759 n. 1 (1962).

228. See, e.g., Bernard D. Meltzer, Labor Unions, Collective Bargaining, and the Antitrust Laws, 6 J.L. \& ECON. 152, 152 (1963) (positing a tension between national labor policies and the objectives of antitrust laws); see also ANTON G.O. SMITSENDONK, TRADE AND LABOR: Two AMERICAN POLICIES 81-86 (1971) (same).

229. See, e.g., Nat'l Ass'n of Mfrs., Organized Labor and the Antitrust Laws-Industry's View, in LABOR \& ANTI-TRUST LEGISLATION, supra note 227, at 71 ("[I]t is a matter of timely information that a double standard exists in the application of the antitrust laws-one under which business monopoly is prohibited, and the other under which union monopolistic practices are freed of restraint.").
} 


\section{Normal Science Case Law and "Independent Contractor" Workers}

The prior statement, in Part I, that the labor exemption is receding through the mechanism of the independent contractor form, can now be restated as follows: the normal science labor exemption largely has no space for the newly ascendant forms of the labor relationship in the current period of breakdown-forms outside the category "employee." The normal science case law also assumes as a factual matter the centrality and strength of labor organizations engaged in NLRA-based collective bargaining. Both ways, it is primarily focused on borderfixing issues. The border defined by employee status was, as set out supra, imported into the labor exemption case law by the reliance upon the larger set of affirmative labor legislation of which Norris-La Guardia was a part. The inevitable implications were then drawn out in the first cases dealing with independent contractor workers and the labor exemption.

Taylor v. Local No. 7230 made the implications of Hutcheson and Apex Hosiery for workers outside the category "employee" concrete and explicit.231 In other words, it manifested the implications of the resultsfocused reliance upon employee status embodied by Norris-La Guardia and the foundational case law, over the more principled distinction between labor and commodity earlier promised in the Clayton Act. The latter distinction may have saved the conduct punished in Taylor, while the former did not. The distinction between the two roads is especially dramatized by the court's recognition, in Taylor, of the independent contractors as occupying the social and economic space of workers. In this, they retained some of the pre-New Deal consciousness of who workers are apart from the "employee" label even as they apply the new legal demarcation to decide whether workers' collective action will be saved from antitrust.

230. 353 F.2d 593 (4th Cir. 1965).

231. The U.S. Supreme Court's very brief opinion in Columbia River Packers Ass'n v. Hinton, 315 U.S. 143 (1942), actually preceded Hutcheson and just followed Apex Hosiery. It held that a fisherman's union (affiliated with the CIO) was an organization of independent businessmen and sellers of commodities, not employees, and moreover, that the employment relationship was not the matrix of the controversy. Id. at 147. Thus, the fishermen's collective refusal to sell to a particular dealer was not protected by the labor exemption. Id. The fishermen may have been among the earliest casualties of the presumption of antitrust liability solidified by the New Deal labor exemption. I choose to discuss Taylor in greater detail for two related reasons. First, it is a clearer illustration of the actual boundary of the labor exemption, because Columbia River Packers Ass'n at least involved sellers of a physical commodity rather than the sellers of pure labor or services. Second, Taylor demarcates that narrower boundary after the dust had settled from the initial, defining labor exemption decisions, rather than while the ground was shifting. 
Taylor applied the framework created by Hutcheson in applying the labor exemption to antitrust:

[I]t is well settled that provisions of the Sherman, Clayton and Norris$\mathrm{La}[]$ Guardia Acts must be considered together in determining the scope of the exemption of union activities from the antitrust provisions; and, in the light of such consideration, the test to be applied in determining whether such activities are exempt is whether they present a case which can be said to involve or grow out of a "labor dispute."232

The court went on to adopt the suggestion of Milk Wagon Drivers 233 and Columbia River Packers Ass' $n^{234}$ taken together, that unless either the parties stood in the relationship of employer and employee or the employment relationship was the "matrix of the controversy," the labor exemption could not protect their conduct from antitrust liability.235 Taylor engaged in a lengthy inquiry about whether the defendant horseshoers were in fact employees or independent contractors, concluding that because they were independent contractors, their concerted action was subject to prosecution. 236

Taylor thus extends the rule that Columbia Rivers Packers Ass' $n$ had formulated for "sellers of commodities" to individuals whom the court itself plainly considers workers. Unlike the earlier Supreme Court case, the Taylor court never used such words as "sellers of commodities." Indeed, the term "independent contractor" itself is suggestive of the fact that the individual is primarily selling labor, not some physical fruit of labor. The court certainly spoke as if it considers them workers, importing its social understanding of work:

Pressures of economic necessity to work in order to provide for one's family and to accommodate the needs of the person who is paying for

232. Taylor, 353 F.2d at 602

233. Milk Wagon Drivers' Union Local No. 753 v. Lake Valley Farm Prods., Inc., 311 U.S. $91(1940)$.

234. 315 U.S. 143.

235. Taylor, 353 F.2d at 604-05. Milk Wagon Drivers held that disputes in which individuals engage in collective action can be immunized by the labor exemption if the employment relationship is the matrix of the dispute, even where the employment relationship at issue is someone else's-thus effectively protecting secondary action, either in solidarity with other workers or targeting actors who do business with one's employer. Milk Wagon Drivers, 311 U.S. at 99-100; see also New Negro All. v. Sanitary Grocery Co., 303 U.S. 552, 560 (1938) (using the same reasoning to immunize a consumer boycott, aimed at employment practices, under the labor exemption). Interestingly, this minor strain of jurisprudence, which has not been overruled, preserves an option for non-employee workers that has long since been closed off under the NLRA.

236. Taylor, 353 F.2d at 597-600. 
the services are applicable to every person engaged in a trade, calling or profession for gain and are not relevant considerations in determining whether one is an employee or an independent contractor. It goes without saying that independent contractors, as well as employees, must work to support themselves and their families and must make themselves available to render services at such times as they are needed. 237

The relevant distinction was at this point definitively not between "labor" and "commodity" (a possibility that the Clayton Act held out), but between workers who are "employees" and "independent contractors" (not even simply between those who are "employees" or not). The court engaged in no discussion of what policy might be served by drawing the demarcation thus, but it certainly does import its own social understanding of how workers are supposed to "accommodate" the "needs" of those they are "serv[ing]," by "making themselves available to them." It clearly identified these "independent contractors" as "persons" engaged in "work," in a "trade, calling, or profession." While one response to the suggestion of this Article may be that it is too difficult to draw the line between non-employees who are workers and those who are not for purposes of antitrust liability, Taylor demonstrates both that there is a fairly strong collective intuition (including on the part of conservative, pro-market courts) that such a category exists, and that it is not impossible to determine who is in it.

The normal science case law as to independent contractor workers was generally in accord with Taylor, 238 while providing for some exceptions to the general rule that worker collective action was completely barred by antitrust. The exceptions are of limited application to the problem at hand. First, a limited exception, based on American Federation of Musicians v. Carroll 239 and its progeny, allows collective bargaining on behalf of independent contractor workers in certain circumstances. The Carroll exception applies only where an established labor organization already represents a critical mass of employees in the workplace or sector, and is grounded in those other

237. Id. at 597 (emphases added).

238. See, e.g., L.A. Meat \& Provisions Drivers Union, Local 626 v. United States, 371 U.S. 94, 104 (1962) (antitrust barred independent contractor drivers from union membership); Spence v. Se. Alaska Pilots' Ass'n, 789 F. Supp. 1007, 1011 (D. Alaska 1990) (union of independent contractor pilots impermissible under antitrust).

239. 391 U.S. 99 (1968); see also H.A. Artists \& Assocs. v. Actors' Equity Ass'n, 451 U.S. 704 (1981) (allowing collective-bargaining agreements that stage actors and actresses, independent contractors, entered into with major theatrical producers). 
workers' statutorily recognized interest in effective bargaining (not in the independent contractor workers' interests). The relevance of Carroll is profoundly limited for today's independent contractor workers, in that traditional labor organizations have little density in the industries in which such workers labor. This exception is also aimed at the "nonstatutory," collective bargaining aspect of the exemption, rather than at unilateral worker collective action. The second primary exception, based on the earlier Milk Wagon Drivers case, does reach unilateral collective action, but generally only protects independent contractor workers who are organizing specifically toward employee status, not those who are engaging in concerted action to directly better their conditions, or for other purposes. 240

\section{ANTITRUSt Liability FOR WORKER COLleCtIVE ACTION: THE VerY IDEA}

As we already saw, the New Deal put a fairly abrupt stop to the use of antitrust law to quash most collective worker action in the manner that had been opened up by Workingmen's Amalgamated and the Danbury Hatters case. But as we also saw, the fundamental proposition that the internal logic of antitrust law required worker collective action to be subject to liability remained in the deep structure of the law, a legacy of those early cases. Modern antitrust law thus directly inherited that proposition from Gilded Age courts, which expressly relied on a specific conception of the social good (one we would not now accept) to justify it. At the same time, the ideology associated with modern antitrust created increasingly rigid divisions between the economic sphere of life and other spheres, notably the social and political spheres. In this final Part, I examine the maintenance of this underlying assumption in the present era as one contingent policy decision among many, which together constitute actual markets. Maintaining the underlying rule involves normative commitments: making those explicit will allow us to decide whether they can be improved.

240. Milk Wagon Drivers, 311 U.S. at 102-03. The exception is further described in note 235, supra. Note, further, that organizing specifically for improved wages and working conditions ought to be within the scope of this exception, so long as employee status is also among the aims (under the test that the dispute must relate to terms and conditions of employment). 


\section{A. The Inherent Normative Content of Punishing Worker Collective Action Under Antitrust}

The modern justification for punishing worker collective action through antitrust law, no less than the classicist one and no less than a policy of exempting worker collective action, rests on specific normative judgments that are neither politically neutral nor selfevident. 241 The difference is that while the classicists were relatively overt and direct in their appeals to a specific conception of the social good-one which entailed a hierarchical suppression of workers' agency in service of constructing a new market-in modern antitrust law that category of consideration (to say nothing of appeals to social hierarchy specifically) has gone largely underground.

Antitrust law enshrines the ideals of the market societycompetition, open markets, and prices that are determined accordingly - and seemingly reinforces the idea of a "singular ideal type of market." 242 At the same time, it embodies the proposition that those ideals require affirmative state action for their realization: state policies that encourage "pro-competitive" conduct by commercial actors and discourage "anti-competitive" conduct.

Antitrust law itself, leaving aside how it plays out in the price-fixing or boycott doctrine or its application to labor, is thus an embodiment of the fact that the market society is not some "natural" or default state of affairs but, on the contrary, the product of an affirmative and often costly set of policy decisions on the part of the state itself. ${ }^{243}$ Today, competition is something that courts undertake to promote, and various

241. This argument, which I make here with respect to its relationship to labor, has been widely made with regard to modern antitrust law generally. See, e.g., Michael S. Jacobs, An Essay on the Normative Foundations of Antitrust Economics, 74 N.C. L. Rev. 219, 226 (1995) (arguing that "the contemporary debate between antitrust economists demonstrates how efforts to base antitrust policy solely upon economic theory inevitably draw on political assumptions about the marketplace"; that "inconclusive evidence of the efficiency effects of many business practices, and the inability of economic theory to determine which model promises greater efficiency, expose these political assumptions and effectively transform the economics debate into a political one"; and that "antitrust discourse would benefit from the acknowledgment by policymakers that the current economic debate is theoretically and empirically irresolvable, and from their express recognition that the choice between conflicting economic models constitutes a normative ordering of divergent political beliefs").

242. Frank Dobbin \& Timothy J. Dowd, The Market that Antitrust Built: Public Policy, Private Coercion, and Railroad Acquisitions, 1825 to 1922, 65 AM. SOC. REV. 631, 631 (2000).

243. Id. ("In economic sociology, an emergent camp contends that antitrust and other policies actively constitute market characteristics. These sociologists suggest that markets may take a variety of different forms rather than conforming to a singular ideal type, and that antitrust policy contributes to this variety rather than serving merely to correct markets that have strayed from the ideal type."). 
policies and practices by private actors are to be evaluated specifically according to whether they promote competition. This is truly a far cry from the original classicist position on markets, according to which almost anything a private actor did in furtherance of interest was, ipso facto, competition. The very idea that competition is a normative ideal separate from what firms actually do in furtherance of their economic self-interest makes space for affirmative state intervention (to bring affairs closer to that normative ideal). To be sure, the classicists had a notion of legitimate and illegitimate competition, but that distinction was drawn on the basis of moral or normative concepts distinct from competition itself. In the neoclassical framework, by contrast, competition itself is the normative benchmark used by antitrust. In other words, the classical framework put bounds on the acts of market actors, but on the basis of conflict between competition and other normative ideals. The neoclassical framework bounds the acts of market actors on the basis of ideal of competition itself. That fact betrays the irreducible normative content of the concept of competition as it is used by contemporary courts, over and above the content of the concept of competition employed by classicist courts.

The law of price-fixing is about preventing restraints on competition, or coordinated conduct that tends to have anti-competitive effects. The reason that I say there is an irreducible normative component in its application is that some restraints on competition are always present in a market; they function as the walls within which competition will take place. At the most basic level, these include all sorts of commercial regulation such as the rules defining and legally constituting the entities that will engage in competition, as well as industry-specific regulation. The goal of "maximizing competition" is simply not tenable, as a practical and logical matter, without incorporating some kind of limits. Then it is an unavoidable question what those appropriate limits, embodied for example in the scope of the price-fixing law, are. The limits we actually have are arguably as much the result of historical accident as they are of rational economic science. Thus, the logic of price-fixing has an inherent openness or indeterminacy, such that effectively extrinsic normative considerations are necessary to determine the precise circumstances under which concerted action to constrict supply of a given commodity is prohibited by antitrust law. The role these considerations play is rarely overt; courts typically fold them under the concepts of "maximizing competition" or "legitimate competition."

This is particularly so with respect to antitrust's relationship to labor, which was formed under the pressure of normative considerations that 
would likely not be endorsed openly by today's courts. That relationship raises a set of normative questions no matter how it is constituted-not only if labor is exempted from antitrust prosecution. One can imagine a whole variety of arrangements relating antitrust law to labor-from total subjection of worker collective action to pricefixing, treating each worker as an individual firm, and with no labor exemption whatsoever, on one end; to a complete exemption for workers' organizations with no restrictions, on the other. Any of these arrangements would then simply become background legal facts; they would constitute the markets within which economic interactions take place.

\section{B. Doctrinal Fault Lines}

In particular cases, courts make judgments about what circumstances define a commodity's market price, and about whether some exception to the centrality of that normative ideal applies. Courts engaging in neoclassical antitrust analysis make affirmative normative judgmentswhether overtly or implicitly - that are indispensable to their decision to continue to punish worker collective action by means of antitrust law. In this final Section, I explore the ways in which these normative considerations interact with the malleable logic of price-fixing, within three doctrinal pathways: (1) the wayward meaning of price-fixing itself, particularly in contexts that have direct implications for the regulation of worker collective action; (2) the operation of the "professional privilege" to shield certain types of workers and small producers from antitrust liability for concerted action; and (3) the basis on which First Amendment protection is denied to concerted action by workers unshielded by the labor exemption.

\section{The Wayward Meaning of Price-Fixing}

"The statement 'price-fixing is per se illegal' is easy to say, but it immediately raises the problem of defining price-fixing." 244 While one might make the equivalent remark about any legal rule, it is no accident that the price-fixing doctrine draws it. The meaning of price-fixing, and with it the rule, has taken wide pendulum swings over the course of the twentieth century, and the relative consolidation of a neoclassical consensus in the last quarter of that century has in some sense contained the seed of its own unraveling, opening the latest door for courts to take the broader perspective urged in this Article.

244. HYLTON, supra note 13, at 117. 
The "per se rule" is that certain activities are violations of the Sherman Act regardless of their actual effects on competition in the market (and to a certain extent regardless of intent). The (modern) rationale is one of judicial and administrative economy: rather than tallying all the market effects in a particular case, some types of conduct are considered likely enough to be anti-competitive that they are deemed violations of the Sherman Act without requiring the plaintiff (or agency) to prove up the anti-competitive effects. As courts consider new varieties of potential violations, more activities are incorporated into the per se rule, while certain categories of conduct (and new categories of conduct) remain subject to the "rule of reason."

The per se rule as to price-fixing itself was a stark departure from the common law, which probably enforced certain agreements that would now be considered criminal price-fixing. 245 The rule was narrowly established early on in the Trans-Missouri Freight Ass'n case. ${ }^{246}$ In Standard Oil, the Supreme Court moved away from the per se rule, and partially reinstated a reasonableness test even for express rate-setting agreements, encompassing considerations such as the purpose, power of the parties, and actual effects of the agreement. ${ }^{247}$ In Chicago Board of Trade, the Court again rejected the per se rule and made a distinction between restraints that "merely regulate and perhaps thereby promote competition" and those that "may suppress or even destroy competition." 248 This represented a halfway point between the common-law rule (a full-blown rule of reason, where even express restraints of trade could be valid if social benefits outweighed harms) and the per se rule, by creating the category of "regulating and promoting" competition. In its initial form, the rule was probably closer

245. The reason is that not only was price-fixing not a tort or crime under the common law, as already stated in Part II, supra, but also that the definition of price-fixing was very different: common-law courts expressly took into account not only whether the resultant prices were reasonable, but whether the competition-restricting agreement's net social effect was positive: whether the "net effect, taking into account possible consumer benefits, is probably harmful to the public." Id. at 93 . This is in contrast to neoclassical price-fixing cases that expressly disavowed potential offsetting consumer benefits, not to mention potential "non-economic" social benefits.

246. Id. at 90-94. See generally United States v. Trans-Mo. Freight Ass'n, 166 U.S. 290, 372-73 (1897) (rejecting the common-law reasonableness standard and refusing to consider the defendants' argument that the prices set were reasonable, apparently implying that contracts in restraint of trade might be reasonable overall).

247. See generally Standard Oil Co. v. United States, 221 U.S. 1 (1911) (replacing the per se test with a reasonableness test); HYLTON, supra note 13, at 101-02 (discussing the decision in Standard Oil).

248. Chi. Bd. of Trade v. United States, 246 U.S. 231, 238 (1918); see also HYLTON, supra note 13, at 104-06 (discussing the decision in Chicago Board of Trade). 
to the broad common-law rule of reason; it evolved considerably away from that as neoclassicism took greater hold. Chicago Board of Trade-unlike some other cases from the period that took the rule further-actually remains good law. The battle has been in applying the rule, in particular regarding the definition of "pro-competitive" and regarding the distinction between regulating competition in a manner that enables it (permissible) and restricts it (impermissible).

Especially instructive is Appalachian Coals, ${ }^{249}$ which extended Chicago Board of Trade almost back to the common-law rule of reason analysis, holding that price-fixing does not intrinsically violate the Sherman Act if the benefits outweigh the harms, and taking a fairly broad view of the category of benefits that may be considered. Although not a labor case, the reasoning and facts of Appalachian Coals are of particular relevance to labor markets. The Court's reasoning was that in a market characterized by large, organized buyers that "created monopsonistic conditions on the demand side, depressing market prices," an agreement to reduce or eliminate competition may be permissible.250 The Court cited several manifestations of "destructive competition" obtaining in the market for bituminous coal prior to the agreement between the sellers, all of them flowing from these monopsonistic conditions. ${ }^{251}$ This, of course, is the situation of many labor markets, particularly heightened by destructive competition on the product market side. 252

This doctrinal uncertainty was connected with and reflected the ideological and policy ambiguity already mentioned regarding the economic vision and policy of the New Deal era. Overall, the market framework seemed to retain the upper hand ideologically, while the active management and containment of markets dominated policy on the ground. For example, initially, the ICC, an agency that engaged in active economic policy-setting, ${ }^{253}$ wanted to allow rate agreements in various industries, while the Justice Department wanted to prosecute

249. Appalachian Coals v. United States, 288 U.S. 344 (1933).

250. HYLTON, supra note 13, at 108.

251. Appalachian Coals, 288 U.S. at 361-64.

252. In fact, the Court noted the "destructive" labor market effects of ruinous competition in the bituminous coal market absent the agreement between the producers, as one of its justifications for allowing the agreement. Id. at 364 ("[W]ages to labor have been substantially lessened."). The point I am making here is that the reasoning of Appalachian Coals can apply directly to labor markets, in addition to sometimes justifying price-fixing in an adjacent commodity market.

253. See BELZER, supra note 33 , at 55 (discussing the ICC). 
them under the Sherman Act. 254 The Reed-Bulwinkle Act, enacted in 1948,255 ended this standoff by legalizing rate agreements among railroads and motor carriers as long as they were approved by the ICC. ${ }^{256}$ These industries were early strongholds of organized labor, and this compromise represented the temporary triumph of the tripartite economic governance of markets previously mentioned. De facto rate setting, with a significant role for organized labor, in product markets characterized other key industries as well. ${ }^{257}$

Eventually, of course, this tripartite model of economic governance was dismantled, with the "deregulation" policy that began in the 1970 s, culminating in the actual dismantling of the ICC. What Michael Belzer has called "deregulation policy" really consisted of changing the state's role in economic governance, reducing its ability to directly engage in economic policy setting in the general interest, ${ }^{258}$ leaving it to other means (including directly regulating workers and imposing personal penalties), often to compensate for problems caused by rampant competition, the removal of any role for labor in economic governance, and the decimation of labor standards. ${ }^{259}$ For example, in trucking, the state role in the mid-century era was characterized by the ICC's rate setting and other direct engagement in economic policy. These essentially ensured a lack of undercutting among both firms and drivers, with the result that public safety was not a major problem. ${ }^{260}$ After

254. HYLTON, supra note 13 , at 97-98.

255. Reed-Bulwinkle Act of 1948, ch. 491, 62 Stat. 472 (codified as amended at 49 U.S.C. $\S 10706(2012))$.

256. See HYLTON, supra note 13, at 98 (discussing the Reed-Bulwinkle Act); see also Belzer, supra note 33, at 59-61 (discussing the Reed-Bulwinkle Act).

257. See, e.g., ThOMAs GeOGHEgan, Before the Lean Years, in WhICH SIDE ARE YOU ON? TRYING TO BE FOR LABOR WHEN IT'S FLAT ON ITS BACK 40, 40-58 (2004) (recounting the United Mine Workers' critical role in coordinating the coal product market).

258. For example, the policy of deregulation in the American trucking industry began in 1977 when the ICC began to loosen the regulations that defined each carrier's pricing. BELZER, supra note 33, at 28. Some companies failed; others began the pressure on their workers to cut wages. Id. The policy was ratified by Congress, and took root in earnest, with the Motor Carrier Act of 1980, which affirmed the earlier administrative deregulation of interstate trucking by removing regulatory barriers to enter into the market, eliminating indirect routings, and permitting discriminatory pricing (allowing discounts to high-volume customers). Id. For the first time since the 1930's, below-cost rates were legal, enabling overt undercutting. Id. In 1994, Congress accomplished the deregulation of intrastate trucking as well, ordering states to stop regulating local trucking by enacting the Federal Aviation Administration Authorization Act. Federal Aviation Administration Authorization Act, 49 U.S.C. 14501; see BELZER, supra note 33, at 28.

259. See supra Part I.B, at notes 33-37 (describing the labor market effects of deregulation in trucking).

260. BELZER, supra note 33 , at 25 . 
"deregulation," the state's role took the form of a net of safety regulations governing drivers' behavior. ${ }^{261}$ Business became the prime actor to directly set economic policy; in the case of trucking, these policy makers were primarily powerful economic actors in adjacent markets, such as retailers, who were increasingly linked to the global supply chain. Thus "deregulation policy" really consisted in a profoundly changed, not eliminated, role of the state in economic life.

The neoclassical turn on the policy level was mirrored in the pricefixing doctrine, so that earlier cases that had extended Chicago Board of Trade to allow various forms of cooperative behavior were largely superseded. Socony established that lack of market power is not even a defense to price-fixing, much less is market power an element of proof, thus prohibiting much cooperative conduct that might otherwise have been permitted.262 Thereafter came the rigid apex of the price-fixing doctrine, embodied especially in Superior Court Trial Lawyers Ass'n and presaged in National Society of Professional Engineers, both decisions involving small producers and both authored by Justice Stevens. ${ }^{263}$ These decisions exemplify the post-Socony regime, which narrowed and clarified the ruling in Chicago Board of Trade. 264 A decade and a half apart, Trial Lawyers can be seen as the natural completion of the logic of Professional Engineers: taking the willful blinders to relational market power, and to potential social and economic benefits of the concerted action, to a certain principled extreme.

However, a contemporary revival of Appalachian Coals for labor markets is made possible by even more recent cases that seem to have again expanded both the scope and the meaning of rule of reason analysis. ${ }^{265}$ Thus, in our current moment "there are pressures to expand

261. Id. at $67-72$.

262. United States v. Socony-Vacuum Oil Co., 310 U.S. 150 (1940); see also HYLTON, supra note 13, at 109 (discussing the Socony case).

263. See Fed. Trade Comm'n v. Superior Court Trial Lawyers Ass'n, 493 U.S. 411, 424 (1990) (refusing to consider social justifications and reasonableness of prices, in considering alleged price-fixing); see also Nat'l Soc'y of Prof'l Eng'rs v. United States, 435 U.S. 679, 69394 (1978) (refusing to consider public safety and other quality or consumer benefits as defense to alleged price-fixing).

264. See Socony, 310 U.S. at 211-12 (narrowing the rule of reason so that only effects strictly tied to promoting market competition could be considered).

265. See United States v. Brown Univ., 5 F.3d 658, 664 (3d. Cir. 1993) (allowing consideration of quality-enhancement arguments under the rule of reason, indicating a softening of the National Society of Professional Engineers approach); see also Broad. Music Inc. v. Columbia Broad. Sys., 441 U.S. 1, 22-24 (1979) (allowing an exception to price-fixing for the introduction of a new product). 
rule of reason analysis" to justifications beyond strictly promoting market competition.266 So far, the benefits of any relaxation seem to have flowed mostly to large market actors, with small actors mostly left by the wayside. ${ }^{267}$ Some contemporary antitrust commentators, notably Warren Grimes, have argued that we ought to effectively return to the analysis of Appalachian Coals by considering relational market power as a basis for allowing concerted action among smaller, less powerful market actors-including, paradigmatically,

professionals (such as doctors or lawyers) who practice individually or in small groups and must do business with power buyers of their services; small businesses (such as independent pharmacies or bookstore owners) ... that confront power buyers and sellers; small franchisees...; small farmers...; and any independent contractor that sells services to a power buyer (such as a taxicab driver or a truck owner ..... ${ }^{268}$

The arc of the price-fixing doctrine demonstrates that it contains no inexorable logic requiring the prohibition of collective action by workers or other small economic actors who earn their income primarily through labor, and in fact contains materials to build a different approach.

\section{The Professional Privilege}

In addition to the pliabilities in the concept of price-fixing just discussed, courts also sometimes invoke the status of sellers as members of one of the traditional professions, either to justify rule of reason rather than per se treatment, or as a consideration among others in the application of the rule of reason. It is thus a privilege rather than an exemption, and its reach is fairly limited, particularly under the influence of neoclassicism-although we may see it expand under the same pressures mentioned relating to the rule of reason. I mention it separately from the other pliabilities described above only because of its likely roots in very early trade regulation, and because the same privilege is not accorded to workers or sellers who lack the social and economic status of the professions. Like all the pliabilities, it represents normative considerations outside neoclassical theory, but this set at once hearkens to animating ideals of pre-market economy trade

266. HYLTON, supra note 13 , at 109.

267. Grimes, supra note 12, at 221-22.

268. See id. at 196-97 (arguing antitrust should allow "countervailing power through the collective action of small buyers or sellers"). 
regulation, ${ }^{269}$ and demonstrates the continuing thread of greater legal privilege within economic regulation accorded to those with greater social and economic status.

The professions have, even in the heyday of neoclassical influence, remained at least partially staked out as a place where courts acknowledge that market forces may not be appropriate to determine all aspects of economic life. It is thus one more way in which the pricefixing doctrine on its own terms admits that market competition need not, and perhaps ought not, govern all of economic life, but, then, reserves the benefit of this restraint largely to socioeconomic elites. For example, in Goldfarb v. Virginia State Bar, ${ }^{270}$ although the Court rejected the wholesale exclusion of the learned professions from antitrust law (noting that lawyers are vital to commerce), it also treated as obvious the idea that the professions ought to be treated differently from other commercial actors, and perhaps with greater deference. Seemingly limiting its holding (allowing the possibility of antitrust liability) to the facts before it, the Court asserted:

The fact that a restraint operates upon a profession as distinguished from a business is, of course, relevant in determining whether that particular restraint violates the Sherman Act. It would be unrealistic to view the practice of professions as interchangeable with other business activities, and automatically to apply to the professions antitrust concepts which originated in other areas. The public service aspect, and other features of the professions, may require that a particular practice, which could properly be viewed as a violation of the Sherman Act in another context, be treated differently. We intimate no view on any other situation than the one with which we are confronted today. 271

This is a very clear statement that the professions ought to be treated differently from other producers or workers in applying the Sherman Act, and that greater deference is due their concerted action. Yet workers outside the professions may also have legitimate claims to a more republican form of regulation of their economic activity. Moreover, considerations relating to the public interest may support those claims, both because of how poor working conditions affect matters such as public safety, and because of the ripple economic and social effects of poverty itself.

269. See supra Part II.A, at notes 79-84 (discussing pre-classicist trade regulation).

270. 421 U.S. 773 (1975).

271. Id. at $78 \mathrm{n} .17$. 
In fact, the professional privilege reflects the resilience, even in the face of neoclassicist ideology, of the deep-seated collective intuition that those who are doing the material work of economic life are entitled to a role in governing it and that indeed we all benefit when they do. The guild economy to which the professional privilege hearkens back was certainly organized around that supposition. 272

Although the neoclassical turn in antitrust doctrine certainly limited the professional privilege, the greater current porousness in the rule of reason offers the possibility of its re-expansion. It is thus relevant both as a point of contrast to the law's treatment of other workers, particularly low-wage workers, and as another doctrinal basis (if mostly by analogy) for excluding worker collective action from antitrust liability, or seriously limiting its scope.

\section{First Amendment Protection for Worker Collective Action?:} "Economic" and "Political" Protest

The analysis of First Amendment protection for worker collective action (not immunized by the labor exemption) also demonstrates how essentially extrinsic normative considerations enter into antitrust doctrine. In this case, an artificial distinction between the "economic" and the "political" keeps First Amendment protection for a classic workers' boycott at bay.

I have previously described Trial Lawyers as an instance of the neoclassical price-fixing logic applied to worker collective action that looms as a serious threat, if not an outright blockade, to much nontraditional worker organizing, particularly on the part of independent contractor workers not affiliated with a traditional labor organization. ${ }^{273}$ It is also a prime illustration of how courts may treat a First Amendment defense to antitrust liability for worker collective action. In this case, the court of appeal had reversed the trial court's finding of liability, reasoning that the expressive component of the boycott was protected by the First Amendment to the extent of nullifying the per se treatment, which would otherwise apply to a "classic restraint of trade." The court of appeal had imposed on the

272. See supra Part II.A, at notes 79-84 (discussing pre-classicist trade regulation).

273. In the case discussed here, the workers' association did not try to claim softer treatment based on their status in the professions, nor on the basis of the labor exemption (despite using much of the language and strategy of traditional labor collective action in the actual conduct at issue). This is not entirely surprising given the narrowness of the labor exemption as previously described, and the neoclassical tightening of the professional privilege, which would have been at its height. 
FTC the requirement of showing "significant market power" on the part of the conspirators. The Supreme Court first agreed with the court of appeal that "this constriction of supply is the essence of 'price-fixing,' whether it be accomplished by agreeing upon a price ... or by agreeing upon an output, which will increase the price offered."274 It then rejected both the association's First Amendment argument based on Claiborne Hardware, which urged that even if the conduct violated the Sherman Act it was protected as an expressive boycott, and the court of appeal's First Amendment reasoning based on O'Brien, which had held that the expressive components of the conduct warranted rule of reason treatment (inviting a consideration of market power and reasonableness of prices). ${ }^{275}$

In distinguishing Claiborne Hardware, the Court places "equal respect" and "equal treatment" beyond the market, and reasoned that the First Amendment protects concerted action, including collective refusals to deal, as long as they are aimed at securing such "equal respect" and "equal treatment."276 "Equality and freedom are preconditions of the free market, and not commodities to be haggled over within it." 277 As if by poetic contrast, the opinion immediately goes on: "The same cannot be said of attorney's fees." 278 The Court dwelled little on the material reality of the lawyers' lives, instead immediately going on to characterize them as "business competitors who stand to profit financially from a lessening of competition in the boycotted market."279 This account essentially characterized pay for personal labor as "financial profit," a result that is compelling neither on neoclassical economic theory nor on a broader view of human labor. Remember that the conduct specifically being sanctioned here was simply the collective refusal to work: the closest resemblance in perhaps all the price-fixing case law to classic labor concerted action. Indeed, that the lawyers had little else to leverage but their personal labor, which was therefore really all they owned, is evidenced by the fact that that is exactly what they did. Note that it was generally agreed that the fees were reasonable and a better public policy in terms of the defense of indigent clients provided by the lawyers. ${ }^{280}$ There is an irony in the

274. Fed. Trade Comm'n v. Superior Court Trial Lawyers Ass'n, 493 U.S. 41 1, 423 (1990).

275. Id. at 426-36 (citing NAACP v. Claiborne Hardware Co., 458 U.S. 886 (1982)).

276. Id. at 426 .

277. Id.

278. Id.

279. Id. at 423.

280. Various court and bar committees that had been convened to study the issue, and likely 
fact that the articulation of the apex of the neoclassical logic of pricefixing - which must ultimately ground itself in the idea that markets, defined by self-interested economic action, ought to be the basis for organizing all economic life-would seem to moralize about relatively low-income, low-status attorneys taking action in their economic selfinterest. ${ }^{281}$

Secondly, there is a circularity in asserting that equality to which one is "constitutionally entitled" 282 is beyond the reach of the market, in order to answer the question to what is one constitutionally entitled. In fact, the only way to avoid that circularity is to acknowledge that, of course, we are actually discussing two different constitutional questions: whether the object of the boycott is constitutionally protected (in the case of Claiborne Hardware, ${ }^{283}$ by the Fifth and Fourteenth Amendments) and whether the boycott is constitutionally protected (by the First Amendment). Certainly, race discrimination is prohibited by the Constitution, ${ }^{284}$ while low attorneys' fees, and even poverty wages, are not. But is the rule really that an expressive boycott is entitled to First Amendment protection only if its object is constitutionally protected? Clearly, that is not the rule. Perhaps what the Court meant to say instead is that the object of a constitutionally protected boycott cannot be an affirmatively illegitimate one, as defined by antitrust. Note, though, that this too compares apples and oranges: seeking higher attorneys' fees (putting aside for the moment whether they should be characterized as financial profit or pay for labor) is not, as a purpose for action, illegal under the antitrust laws. The conduct as a whole must be analyzed under the antitrust laws to make a determination about legitimacy. Put aside even that issue and assume the lawyers' conduct did violate the Sherman Act. To rely upon that alone is simply to eviscerate the constitutional limits on antitrust when it comes to expressive boycotts. One can imagine, in other words, a rule that the

the political branches of the District of Columbia as well, endorsed the higher rates as a policy matter, citing in particular the impact upon the quality of representation. Id. at 444-46.

281. It is, perhaps, the smallest whiff of the double standard that the market framework seems to embody when plumbed deeply enough in any one place: freedom and self-interest for the haves, morality and self-denial for the have-nots.

282. Superior Court Trial Lawyers Ass'n, 493 U.S. at 426.

283. NAACP v. Claiborne Hardware Co., 458 U.S. 886 (1982).

284. This is putting aside an issue that the opinion glosses over-that the Constitution does not literally guarantee the aims of the Claiborne Hardware boycotters, to the extent that the underlying wrongs did not involve state action. Presumably, the Court is relying upon the constitutional principle to distinguish between the aims of the two sets of boycotters. However, this issue further highlights the lack of clarity around what that principle is. 
First Amendment only protects expressive boycotts that would not otherwise be violations of the antitrust laws. Perhaps all the foregoing complexities serve to avoid stating such a bold rule outright. We will never really know, because the Court dispensed with the Claiborne Hardware argument on the basis of what it painted as an extreme contrast between the objects of the two sets of concerted action (constitutionally hallowed on one end, illegal on the other end).

The Court also seemed to rely partially on its relatively offhand, closing statement that Claiborne Hardware does not protect economic boycotts, distinguishing those from the "peaceful, political activity" involved in the earlier case. ${ }^{285}$ But this distinction is not tenable. Boycotts by definition involve an economic act: the collective refusal to buy or sell, in an attempt to influence some specific behavior of the one from whom one has been buying or selling. The two cases are not distinguishable in any salient respect as to their employment of this means. The other points of comparison are the objects of the means employed, and any other means used. As for the latter, the Court conceded that the lawyers engaged in various expressive activity that was political in nature. In the lawyers' case, the Court separated this conduct from the economic boycott; 286 yet, in the civil rights boycotters' case, the Court ran this conduct together with the concerted refusal to buy. ${ }^{287}$ As for the purposes of the boycotts, the rule would then have to be that boycotts aimed at bringing economic benefits to the boycotters ${ }^{288}$ are not entitled to First Amendment protection. Surely this cannot be the rule, since many of the benefits sought by the boycotters in Claiborne Hardware were also economic in nature. To be sure, those economic benefits were grounded in a claim for racial justice, but if that (or some other constitutionally protected value) is the requirement, then we are back at the circular argument just described.

The Trial Lawyers Court then turned to the court of appeal's reasoning that even if not protected wholesale, the lawyers' conduct was entitled to a softened rule of reason treatment due to the First Amendment implications. ${ }^{289}$ The Court rejected this partially on the

285. Superior Court Trial Lawyers Ass ' $n, 493$ U.S. at 428.

286. See, e.g., id. at 431 ("[T]his level of expression is not an element of the boycott.").

287. Id. at 428.

288. Emphasizing its economic aspects, the Court calls what the lawyers sought variously "attorneys fees," "special advantage," "economic[] advantage," "[financial] profit." Id. at 42728. The idea of "special advantage," again, implies a counterfactual embedded with normative assumptions. Id.

289. Id. at 429. 
basis of the same distinction between the economic and the political that it mentioned in its rejection of the Claiborne Hardware argument, but also on the basis of an analysis of the role of market power in pricefixing analysis. ${ }^{290}$ The former, as just described, is based upon an artificial and selective separation of the expressive and the economic components of the concerted action, which in turn points up the artificiality of the distinction in the first place. The latter is based on a perhaps exaggerated solidity of the "rule of law" that the lawyers supposedly violated. 291

Even most theorists who assume that antitrust should strictly implement economic theory would say that refusing to consider market power is not the best implementation of what that theory would prescribe. ${ }^{292}$ The Court skirted this conclusion. It certainly relied upon what it characterized as the massive administrative inconvenience of analyzing market power. At the same time, it insisted that "the per se rules also reflect a longstanding judgment that the prohibited practices by their nature have 'a substantial potential for impact on competition.""293 The analogy chosen was an odd one:

The per se rules in antitrust law serve purposes analogous to per se restrictions upon, for example, stunt flying in congested areas or speeding .... Perhaps most violations of such rules actually cause no harm. No doubt many experienced drivers and pilots can operate much more safely, even at prohibited speeds, than the average citizen.

... Yet the laws may nonetheless be enforced against these skilled persons without proof that their conduct was actually harmful or dangerous. ${ }^{294}$

290. Id. at $430-36$.

291. These points are also made in Justice Brennan's dissent, which endorses the court of appeal's application of the rule of reason, because that is appropriate in cases of expressive boycotts that have both First Amendment and antitrust implications. Id. at 437-52 (Brennan, J., dissenting). The dissent reasons that the per se rule is a presumption (almost by definition, some practices banned by it would pass the rule of reason), and that in a First Amendment case, the government cannot apply broad presumptions (that certain categories of speech are harmful) without engaging in a more particularized examination. Id. The dissent emphasizes the history of boycotts, and adduces facts specific to this boycott in particular, that show it or them to be in essence a political, rather than or in addition to an economic, tactic to change behavior. Id. It emphasizes that the expressive component of an expressive boycott is inseparable from the boycott activity, rejecting the compartmentalization of the majority's analysis (and rejecting the idea that the minimal expression inherent in every boycott is what makes it fall in the expressive category). Id.

292. See, e.g., HYLTON, supra note 13, at 114 (suggesting that market power should be considered in analyzing antitrust violations).

293. Superior Court Trial Lawyers Ass' $n, 493$ U.S. at 433 (majority opinion).

294. Id. 
But the point is that a group of competitors with insufficient market power don't pose a risk at all, not that the risk is potential but not actual, as it is with obviously and inherently dangerous activity (stunt flying in traffic). It is fairly evident that the lawyers lacked such "relational" market power: the market was characterized by a single large, organized buyer. The same idea-monopsony-motivated Appalachian Coals but had since been largely abandoned by the courts. The results of this imbalance of market power were depressed rates of pay that no one on the ground seriously thought were fair, sustainable, or good policy.

As the deregulation era marches ever forward, bringing with it the continued growth of nontraditional work, the rigidities and tensions of the approach to worker collective action embodied in Trial Lawyers are likely to become more dramatically exposed. If so, we will also be presented with the opportunity to consider that approach afresh.

\section{CONCLUSION}

My aim here has been to trace the history of an idea: the application of antitrust liability to worker collective action. The situation of today's independent contractor workers, who face antitrust liability for engaging in collective action aimed at improving wages and working conditions, starkly confronts us with this issue, and with the deeper questions about the relationship between market regulation and labor regulation that it raises.

The suggestion that I have tried to make is simply that we should reevaluate this rule, and that in doing so, we ought to engage in a truly new examination of the values implicated, freed from the default assumptions-largely accidents of history - that have mostly dogged discussions of the matter. Such an examination may include, to be sure, costs that might result from very strong labor combinations in certain markets. But it also must include the benefits that would result from recognizing and honoring the expression of human agency that worker collective action is, as well as the social, economic, and moral value of decent working conditions and decent wages for work.

Nothing in the core logic of modern antitrust law constrains courts or legislatures from such a reconsideration; in fact, the peculiar history of the default rule examined in this Article demands it. In future work, I will further explore the republican origins of the Sherman Act itself as a potential source for developing a set of considerations that might replace the default rule. To clear the space for that work, I hope to have shown that the apparent logical inevitability of the status quo, which would bring the heavy hammer of the Sherman Act down on worker collective action almost without exception, is illusory. 